\title{
Mitra kuju Indias ja Mithra kuju Iraani usundites - uurimus võrdlevast mütoloogiast
}

\begin{abstract}
Jaan Lahe, Martti Kalda
Teesid: Ideaalset paralleeli (eelkõige esineb sarnasus nimedes, harvem karakterites) veedade mütoloogiast tuntud tegelastele pakuvad Avesta müütilised persoonid, kelledest üks on jumal Mithra (= veedade Mitra).

Mitra (esineb enamasti paaris Varunaga) on seotud kosmilise ja sotsiaalse korraga, samuti kaitseb ta aarialasi ning annetab neile erinevaid hüvesid (viljakus, tervis, rikkus). Ka tema Iraani paarik Mithra on seotud korraga, kuid rohkem sotsiaalse kui kosmilise korraga, olles spetsiifiliselt ustavuse, vannete ja lojaalsuse valvur. Erinevalt veedade Mitrast on ta tugevalt militaarsete joontega (mis veedades iseloomustab eeskätt Indrat), võideldes nii aarialaste inimvaenlaste kui ka deemonitega. Mithra on eriliselt seotud ka kuningavõimuga ning alates Partia ajajärgust samastatakse teda päikesega.

Võrreldes India Mitrat ja Iraani Mithrat võib täheldada, et Mithra kuju on mänginud Iraani religiooniloos suuremat rolli kui Mitra Indias - talle on pühendatud oluliselt rohkem tekste kui Mitrale, temast leidub visuaalseid kujutisi ning tema aktiivne roll ja kõrge positsioon panteonis säilib Iraani kultuuri piirkonnas (mis hõlmab ka Väike-Aasiat, Kurdistani, Armeeniat ja Osseetiat ning ulatuslikke alasid Kesk-Aasias) palju kauem kui Mitral hinduismis. Vaatamata paljudele erinevustele kahe jumaluse kujus on nende indoiraani ühisajast pärinev ühine algkuju väljaspool kahtlust.
\end{abstract}

Märksõnad: Avesta, India, Iraan, Mithra, Mitra, mütoloogia, sanskrit, veedade kirjandus

\section{Sissejuhatus}

Alates sellest, kui Franz Bopp (1791-1867) avastas indoeuroopa rahvaste keelesuguluse, on muistse India ja muistse Iraani hõimude ${ }^{1}$ lähedane sugulus tõestatud. Lisaks veedade ja Avesta kui India ja Iraani indoeuroopa hõimude vanimate ürikute keelesugulusele kajastab seda hästi ka India ja Iraani hõimude mütoloogia. Paljud India ja Iraani muistsed jumalad kannavad sarnaselt kõlavaid ja ka etümoloogiliselt suguluses olevaid nimesid ${ }^{2}$ ning ka nende ise- 
loomus võib leida sarnaseid jooni. Üks selline jumalatepaar on muinaspärsia jumal Mithra (avesta MiӨra, keskpärsia Mihr) ja tema India vaste Mitra.

Käesoleva artikli eesmärk on anda süstemaatiline käsitlus jumalusest, kes kannab Indias nime Mitra, Iraanis aga Mithra, ning vastata kolmele küsimusele:

1) Millised on India Mitra ja Iraani Mithra sarnasused peale jumala nime?

2) Millised on nende kahe jumaluse erinevused?

3) Milliseid muutusi on teinud läbi mõlema jumala kujutamine india ja iraani mütoloogias?

Eraldi uurimisküsimus võiks olla ka nende kahe jumaluse funktsioon muistses India ja Iraani ühiskonnas, ${ }^{3}$ kuid tingituna artikli mahust seda küsimust siin eraldi ei uurita. Et vastata kolmele eelpool nimetatud küsimusele, vaadeldakse artiklis esmalt Mitrat Indias, seejärel Mithrat Iraanis ning viimaks vaadeldakse kahe jumaluse sarnasusi ja erinevusi. Jumalakujude sarnasuste ja erinevuste väljaselgitamiseks kasutavad artikli autorid müüdiuuringutes kuni tänaseni laialdaselt kasutusel olevat võrdlevat meetodit. Mõlema jumala puhul jagatakse tema kuju esmalt koostisosadeks, milleks on jumala nimi, tema erinevad epiteedid ning allikates leiduvad väited jumaluse olemuse ja tema üksikute funktsioonide või tegevuste kohta. Seejärel võrreldakse India ja Iraani jumaluse kuju koostisosi teineteisega ning selle võrdluse põhjal tehakse järeldused. Kumbki artikli pool algab ülevaatega allikatest, milles vastav jumalus esineb ning ajaliste muutuste väljaselgitamiseks puudutatakse ka allikate dateerimist. India puhul on allikad vaid tekstuaalsed, Iraani kultuuriruumis lisanduvad ka visuaalsed allikad - müntidel ja pitsatitel leiduvad kujutised, reljeefid ja maalingud.

\section{Mitra Indias}

\section{I.1. Veedade kirjandus}

Veedade kirjanduse (u 1500/1200-600/500 eKr) erinevad kihistused ja žanrid jagatakse ning dateeritakse enamasti nelja gruppi: Rg-(skr 'värsitarkus'), Athar$v a$ - (skr 'loitsutarkus'), Sāma- (skr 'laulutarkus') ja Yajurveda (skr 'ohvritarkus') (u 1500/1200-1000/800 eKr) (1); brāhmanad ja āranyakad (u 1000-800 eKr) (2); upanișadid (u 1000/800-600/500 eKr) (3); sūtrad (u 600/500-400/300 eKr) (4). 


\section{I.1.1. Rgveda}

Rgveda (skr 'hümnitarkus') tekst oma praegusel kujul sisaldab 1028 hümni (skr sūkta) ja 10462 värssi ehk stroofi (skr rcc). Rggveda on jagatud kümneks raamatuks (skr manḍla - 'ring', 'sfäär'), iga raamat aga sisaldab erineva arvu hümne: esimeses maṇdalas on 191 sūktat, teises 43, kolmandas 62, neljandas 58 , viiendas 87 , kuuendas 75 , seitsmendas 104 , kaheksandas 103 , üheksandas 114 ja kümnendas 191 .

Rgvedas (edaspidi RV) esineb Mitra peaaegu alati koos oma paarilise Varunaga (skr du mitrāvaruṇa), koos kiidetakse neid kahekümne viies tervikhümnis (RV I,136; I,137; I,151; I,152; I,153; V,62; V,63; V,64; V,65; V,66; V,67; V,68; V,69; V,70; V,71; V,72; VI,67; VII,60; VII,61; VII,62; VII,63; VII,64; VII,65; VII,66; VIII,25) ja osades teiste hümnide värssides (näiteks RV I,2,79; I,15,6; I,23,4-6; I,41,7-9; I,43,3; I,122,6-15; I,139,2; II,41,4-6; III,62,16-18; VII,50,1; VIII,101,1-5; X,132,2-7). Mitra ja Varuṇa funktsioonid ja karakterid on teineteisest peaaegu lahutamatud, Mitra iseseisvus piirdub ühe hümniga (RV III,59), üksnes Varunale on Rggedas pühendatud 8 tervikhümni (RV I,25; II,28; V,85; VII,86; VII,87; VII,88; VII,89; VIII,41).

\section{I.1.2. Atharvaveda}

Atharvavedas on 20 raamatut ( $\operatorname{skr}$ kaṇda) ja 731 hümni (skr sūkta) - kokku umbes 6000 stroofi. Vanimad on I-XIII raamat, teistes Atharvaveda raamatutes (peale I-XIII kaṇda) leidub laene Rigvedast.

Atharvavedas (edaspidi AV) on Mitra ja Varuṇa roll mütoloogias Rgvedaga võrreldes tublisti vähenenud. Mitrale ja Varuṇale paaris on pühendatud vaid üks tervikhümn $(\mathrm{IV}, 29)$ ning üksikuid värsse teistes hümnides (näit I,3; I,9; I,18; I,20; II,28; III,4; III,6; III,8; III,25; V,19; V,24; V,25; VI,32; VI,85; VI,89; VI,97; VI,103; VI,125; VI,132; VII,30; IX,3; IX,4; IX,9-10; X,4; XI,6; XI,9; XII,4; XIII,1-3; XIV,1; XVI,4; XVI,8; XVIII,1; XIX,9-10; XIX,44; XX,107; XX,123). Mitra tavapärane kaaslane Varuṇa seevastu leiab Atharvaveda loojatelt suuremat tähelepanu; teda on ülistatud I,10., IV,16. ja V,11. hümnis üksi, ning IV,29. koos Mitraga, V,1. koos Tritaga, VII,25 koos Viṣṇuga ja VII,58. hümnis koos Indraga.

\section{I.1.3. Yajurveda}

Yajurvedast esineb viis teadaolevat redaktsiooni; neist neli (Kāthaka, Kapișthalakaṭha, Maitrāyaṇi ja Taittirīya saṃhitā) moodustavad Musta (skr kṛ̦na) Yajurveda, viiendat - Vājasaneyi saṃhitād nimetatakse Valgeks (skr śukla) Ya- 
jurvedaks. Võrreldes Rg- ja Atharvavedaga ei lisa Yajurveda tekstid Mitra karakteri kirjeldamisse midagi uut, üksikud tekstikohad toetavad väljakujunenud nägemust Mitrast.

\section{I.1.4. Śatapatha brāhmaṇa}

Śatapatha brāhmaṇa (skr 'saja tee braahmana') on üks kõige vanemaid ja mahukamaid brāhmaṇa tekste. Tekst koosneb sajast peatükist (siit ka nimi) ning on loodud umbes 8.-6. sajandil eKr. Kommentaartekstina kuulub Śatapatha brāhmaṇa (edaspidi ŚB) Valge ehk Śukla Yajurveda juurde; kuna Valgest Yajurvedast on säilinud kaks tekstiredaktsiooni: Kāṇva ja Mādhyaṃdina, on ka Śatapatha brāhmaṇal kaks eri redaktsiooni: Kāṇva ja Mādhyạ̣dina koolkonna versioon. Mādhyaṃdina tekstiversioon jagab teose 7624 lõiguks (skr kāṇdika), 100 peatükiks (skr adhyāya) ja neljateistkümneks osaks (skr kāṇda), Kāṇva redaktsioon aga 6806 lõiguks, 104 peatükiks ja seitsmeteistkümneks osaks.

\section{I.2. Mitra kuju veedade kirjanduses}

\section{I.2.1. Nimi}

Mitra tähendab sanskriti keeles sõpra ja kaaslast, poliitikas ja sõjanduses ka liitlast või äripartnerit. Sellest -tā ja -tva järelliite abil moodustatud abstraktsed mõisted (mitra-tā; mitra-tva) aga sõbralikkust, sõprust, vendlust ja võrdõiguslikkust. Omadussõna saab sõnast mitra esiisilbi pikendamise teel: maitra - 'sõbralik' (samatähenduslik on ka maitra-tā). Seega on budismis tuntud tulevase messia-buddha Maitreya nimi kaudselt mitra tuletis, tähendades kaastundlikku ja sõbralikku olendit.

Mitra nime etümoloogia on ebaselge. Nimi pärineb ilmselt indo-euroopa verbijuurest mith = mid - 'ühitama' s.t 'liituma', 'paaris olema' või 'vastanduma', 'kokku põrkama' (Macdonell 1897: 29-30). ${ }^{4}$ Proto-Mitra nimi nagu protoVaruṇagi nimi esineb hetiitide pealinna Boghas Köy lepingutekstis, ${ }^{5}$ s.t, et Mitrat tuleb pidada vähemalt sama vanaks kui tema Rgveda kaaslast Varunat (Mackenzie 1994: 28, 31-32; Jelizarenkova 1972: 309).

Mitra nime puhul viidatakse etümoloogilisele ja tähenduslikule lähedusele indo-iraani sõnaga mihr ('päike', 'sõprus', 'armastus'), mis seob R,gveda Mitra ja Avesta Mithra (Macdonell 1897: 79; Jelizarenkova 1972: 310-311; Puhvel 1997: 323) ning alg-slaavi sõnaga mir ('rahu' aga ka 'kosmos', 'maailm') (Puhvel 1978: 342; Jelizarenkova 1972: 311). 


\section{I.2.2. Mitra Rgvedas}

Rgveda materjali hulgast on raske eristada Mitra ülesandeid mütoloogias. Jumalad Mitra ja Varuṇa (skr du mitrāvaruṇā) moodustavad äärmiselt tugevalt seotud duaalse paari. Mitra on Varuṇa kõrval nii valdjas (skr rājan), ülemvalitseja ( $\mathrm{kkr} s a m r \bar{a} j$ ), kui ka vürst ( $\operatorname{skr} k s ̦ a t r i y a)$ ning võluväe ( $\operatorname{skr} m \bar{a} y \bar{a}$ ) omanik. Mitra toetab Taevast ja Maad, seab Päikese taevasse liikuma, jagab vihma ja valitseb jõgesid, ta on korravalvur, ülevaataja, õigluse kaitsja, karistaja ja abimees hädas. Mitra funktsioonides pole aga isikupära.

Enamiku uurijate (vt Mackenzie 1994: 28; Gonda 1974: 151-153; Macdonell 1897: 29-30) arvates kehastab Mitra päeva (või koidikut) ning Varuṇa ööd (või loojangut). Aluseks on võetud Rgveda I,115,5. värss, kus Mitra on hele ja Varuṇa tume, ning kommentaator Sāyaṇa oletus, mille ta esitab Rgveda I,89,3. ja VII,87,1. lõiku kommenteerides. Teooria autor on uurija R. von Roth (Muir 1870: 58, 69-70). Rgveda tekstist tema mõttekäigule toetust ei leidu, küll aga Atharvavedast (AV IX,3,18; XIII,3,13) ja Taittirīya saṃhitā tekstist (TS I,7,10,1; I,8,16,1; II,1,7,4; VI,4,8,3). Rgveda esitab pigem vastuväiteid (kuigi nime Varuna võiks mõista '[kõike] kattev (s.t. öine) [taevas]'?): Varuṇa on Mitra kõrval särav jumalus (RV VII,88,2), kellel käed ja jalad kui päikesekiired (RV VIII,41,8; VIII,101,2). Mitra ja Varuṇa rõivastust on kujutatud sädelevana (RV I,25,13; I,152,1; VII,64,1) ja nende võimsat vankrit päikesetaolisena (RV I,25,18; I,122,15; V,62,8; VIII,101,2). Toetudes eeltoodud materjalile on raske uskuda, et kõik päikesetaolisusele osutavad viited oleksid Varuna karakterisse sugenenud tema paariliselt või et särav Päike oleks ööjumala hoole all. On raske uskuda, et päikesejumal Mitra oleks nõrgem kui kuujumal Varuna. Selge on, et toetudes päeva ja öö vastandusele Mitra ja Varuṇa funktsioone eristada ei saa, ning Päike ei kuulu eksklusiivselt Mitra võimu alla.

Edward Vernon Arnold väidab, et Mitral on solaarne iseloom vaid seoses tulejumal Agniga, ning et Agni esiletõus Rgvedas surus Mitra kõrvale (Mackenzie 1994: 28, 31). Mitra ja Agni seotusele viitab kahe jumala sagedane samastamine Rgvedas (RV II,1,4; III,5,4; V,3,1; VI,8,3; VI,13,2; VII,12,3): tulejumal on kirgas (RV II,2,3; V,10,2; V,16,1; VI,2,1; VI,3,6; VII,3,6; VII,5,6; VIII,19,25; VIII,60,7; VIII,74,2; X,110,1) ja tugev (RV VI,2,11) nagu Mitra, Agni ühendab rahvaid justkui Mitra (RV VIII,102,12) ning lahutab Taeva ja Maa, hävitab valgusega pimedust justnagu Mitra (RV VI,8,3). Rgveda X,8,4. lõigu kohaselt on Agni Mitra sigitaja. Tihti tegutseb Agni Mitra väge kasutades (RV II,1,5; VI,2,11; VI,5,4; VI,14,6). Koos Mitraga samastub Agni ka Varunaga (RV II,1,4; III,5,4; V,3,1; VII,12,3). Vaid Rggeda I,143,4. värss võrdleb tuld Varuṇaga ilma Mitrale viitamata. Rgveda IV,1,2. lõik nimetab Varunat Agni vennaks. Atharvaveda (AV XIII,3,13) väitel on Agni koidikul Mitra ja ôhtul Varuṇa. 
Jumal Mitra isik on õhutanud mitmeid Rgveda poeetidest filosoofe lisaks sarnasusele Agniga nägema Mitrale omaseid jooni teisteski jumalais. Rgveda paradoksaalsete väidete kohaselt kuuluvad Mitra ja Aryamani sarnasele Somale Varuṇa seadused (RV I,91,3; IX,88,8). Soma on justkui Mitra (RV IX,2,6), Varuṇa (RV IX,47,5; IX,95,4) või Mitra ja Varuṇa paaris (RV IX,100,5). Äikesejumal Indra meenutab Mitrat (RV I,129,10; X,22,1 ja 2) nagu ka päikesejumalad Sūrya (RV X,37,7), Viṣṇu (RV I,146,1) ja Savitṛ (RV V,81,4). Mitra ja Varuṇa tandemiga samastuvad kaks Aśvinit (RV X,93,6) ja Indra (RV X,147,5).

Uurijate Johann Jakob Meyeri ja Alfred Hillebrandti arvates on Somaga samastuv ja sarnane Varuṇa (solaarsete iseloomujoontega jumalad, vee kontrollijad, tarkuse isandad) kuujumal (Hillebrandt [1980] 1990: 22-24, 29-30). Sören Sörensen, Karl Ferdinand Johansson ja Abel Bergaigne viitavad jumal Varuṇa ja Indra peavaenlase deemon Vṛtra sarnasusele (Varuṇa juhib vett, Vṛtra tõkestab vett, nimi samast verbijuurest) ning peavad mõlemat muistseks kuujumalaks. Kahe tegelase erisusele osutab kuulumine erinevatesse müüditsüklitesse (Hillebrandt [1980] 1990: 22).

Teine võimalik Mitra ja Varuṇa erisus lähtub Mitra nimest: tegu on sõpruse jumalaga (RV I,21,3), kes pigem aitab kui karistab inimesi, vabastab neid patust ning juhatab hädas. Rgveda III,59,5. värsis on Mitra epiteediks yātayajjana (skr 'rahvaste kannustaja', 'inimeste õhutaja', 'rahva ühendaja'; Rgveda I,136,3. värsis on see Mitra, Varuṇa ja Aryamani lisanimi; Rgveda V,72,2. lõigus Mitra ja Varuṇa ning VIII,102,12. värsis Agni epiteet). Mitra on vägivallatu jumal, ülevaataja, samas Varuṇa on karm kohtunik. Erinevust rahutu ja vihase Varuṇa ning rahumeelse Mitra karakteri vahel on märkinud juba Georges Dumézil (1988: 117). Tuleb aga mainida, et rahutegija rollis pole Mitra ja Varuna vahel erilist vahet. Mõningaid erinevusi võib loomulikult täheldada: näiteks Mitra on 'sõber' (skr mitra), ent Varuṇa vaid 'kaaslane' (skr sakhi) (RV VII,88,5 ja 6). Erinevused on siiski tühised.

Varuṇa kaitseb inimesi, ent Mitra jagab inspiratsiooni (RV VII,66,3), Varuṇa on kohutav, Mitra leebe (RV VII,82,5), Varuna kaitseb, ent Mitra jälgib inimesi (RV I,23,6). Rgveda IV,5,4. värss eristab Mitra seadusi Varuṇa käskudest. Ilma Varuṇata on Mitra maailma järelevaataja (RV III,59,1; VI,13,2), kelle seaduste järgi kulgeb Viṣnu (RV VIII,52,3) ning toimivad Taevas ja Maa (RV IV,56,7). Mitra ühendab inimesi (RV VIII,102,12) ja kannustab neid (RV III,59,5). Ŗgveda X,12,8. värsis kuulutavad Aditi, Savitṛ ja Mitra inimesi Varuṇa ees süüst puhtaks.

Lisaks sellele, et tegu on jumalate (skr deva) ja Aditi poegadega (skr āditya), on Mitra ja Varuṇa asurad (RV I,151,4; VII,36,2; VII,65,2; VIII,25,4) ning Dakṣa järglased (RV VII,66,2; VIII,25,5). Rgveda X,64,5. värsis viibivad Mitra ja Varuṇa Aditi kutsel Dakṣa sünni juures. Ṛgveda V,70,2. ja 3. nimetab Mitrat-Varuṇat 
Rudrate lisanimega, mis Rgvedas kuulub tavaliselt Marutitele, Rudra poegadele. Mitra ja Varuna on surematud jumalad (RV I,122,11; V,69,4; VII,63,5) ning neid võrreldakse kahe raisakotka (RV I,151,5) ja kahe hobusega (RV VI,67,4). Jumalate kodu asub taevas (RV I,136,2; V,62,7; V,67,2) ja on kuldne (RV V,62,7; $\mathrm{V}, 67,2)$, Mitra ja Varuna kojal on tuhat (RV II,41,5; V,62,6) rauast sammast (RV V,62,7) ning nende troon (skr sadas - 'iste') on lai (RV V,68,5). Varuna majal on tuhat ust (RV VII,88,5). Jumalatepaaril on kullakarvaline kaarik (RV V,62,8; $\mathrm{V}, 63,1)$ ja hobused kaariku ees ( $R V$ V,62,4). Ohvririitusel rüüpavad Mitra ja Varuṇa somajooki (RV I,23,4; I,136,4; I,137,1-3; II,41,4; III,62,18; V,64,7; V,71,3; V,72,1-3; VI,67,7; VII,64,5; VII,65,5; VII,66,17-19; IX,7,8; IX,61,9; IX,85,6; IX,90,5; IX,97,42 ja 49; IX,104,3; IX,108,16).

Mitra ja Varuna on maailmavalvurite ja ülevaatajate duaalne paar (RV I,136,3; V,62,8 ja 9; V,66,6; VI,67,1, 5 ja 7; VIII,25,1,7 ja 9). Informaatorid (RV VI,67,5; VII,61,3) ja Päike jälgivad Mitra ja Varuṇa (RV VII,60,2 ja 3; VII,61,1; VII,63,1) kogu inimkonda. Seetõttu teavad Mitra ja Varuṇa kõike (RV I,151,9; VII,61,5). Päike on Mitra ja Varuna silm, saadik ja vaatleja - maailma nuhk taevas (RV I,50,6; I,115,1; VI,51,1; VII,60,1 ja 3; VII,61,1; VII,63,1; X,37,1).

Jumalatepaar on tegev maailmakorra kaitsel: nad toetavad, kaitsevad ja edendavad seadusi (RV I,2,8; I,23,5; V,63,1 ja 7; V,65,2; V,67,4; V,68,4; V,69,1; VII,64,2; VII,66,10, 12, 13 ja 19) ning järgivad maailmakorda (RV VIII,25,4 ja 8). Mitra ja Varuṇa seadused on vankumatud (RV V,69,4; VIII,25,2, 8 ja 17) ja nad on tugevad just maailmakorra kaudu (RV I,2,8; V,68,4; VII,60,5). Jumalad karistavad süüdlasi ja valetajaid (RV I,152,1; I,167,8; VII,60,5; VII,61,5; VII,66,13; VII,65,3), ent samas ka andestavad süüdlastele (RV II,27,2 ja 14; VII,60,10). R.gveda X,36,12. lõigus vabastab Agni inimesi süüst Mitra ja Varuṇa ees. Indra karistab Mitra ja Varuṇa (RV X,89,8) ning Mitra, Varuṇa ja Aryamani seaduste rikkujaid ( $\mathrm{RV} \mathrm{X}, 89,9)$.

Mitra ja Varuṇa on tõe ja õigluse kaitsjad, seda kinnitavad nende epiteedid r $r \bar{a} v r d h \bar{a}$ (du. 'tõekasvatajad', 'tõe idandajad'), rtāvānā (du. 'korravardjad'), rtajātā (du. 'tõest sündinud', 'tõelised'), rtasprśā (du. 'korrajärgijad'), rtasya gopau (du. 'korrakarjased', 'tõevalvurid') ja rtasya jyotisașpatī (du. 'tõe [ja] valguse isandad') (RV I,2,8; I,23,5; I,136,4; II,27,4; V,63,1; V,65,2; V,67,4; VII,64,2; VII,66,13; VIII,23,30; VIII,25,8).

Mitra ja Varuṇa valitsevad kahekesi ( $R V$ V,63,2 ja 3; V,66,6; V,71,2; VII,60,10) või koos Aryamaniga (RV VII,64,1) maailma, tehes seda seaduste abil (RV III,62,17; V,63,7). Mitra ja Varuṇa on üheskoos valdjad (skr rājan), ülemvalitsejad (skr samrāj) ning vürstid (skr kṣatriya), kelle käes on valitsusvõim (skr kșatra) (RV I,24,6; I,25,5; I,41,3; I,71,9; I,136,1 ja 4; I,137,1; II,41,5; $\mathrm{V}, 62,3$ ja 6 ; V,63,2, 3 ja 5; V,65,2; V,66,2; V,67,1; V,68,1 ja 2; VI,49,1; VI,51,10; VI,67,5 ja 6; VII,34,11; VII,64,2 ja 4; VII,66,6 ja 11; VIII,23,30; VIII,25,4, 7 ja 
8; VIII,101,2 ja 5; X,65,5). Mitra ja Varuṇa kasutavad ühiselt ka võluväge (skr $m \bar{a} y \bar{a})$ (RV III,61,7; V,63,3, 4 ja 7). Rgveda X,36,13. lõigu kohaselt valitsevad Mitra ja Varuṇa koos Savitṛ’ga jumalaid.

Maailmakorra kaitsmisele, ülevaataja ja valitseja ametile sekundeerivad Mitra ja Varuna kosmogoonilised funktsioonid. Jumalad lahutasid Taeva ja Maa (RV V,67,1; VII,61,4) ning seadsid kaks ilma paika (RV V,62,3), nad toetavad Taevast (RV V,69,4; VI,67,6) ja Maad (RV V,69,4), hoolitsevad nende eest (RV VII,60,7) ning on täitnud Taeva ja Maa inimeste jaoks toiduga (RVVI,67,6) - on teinud maailma viljakaks (RV VII,65,2). Rgveda V,62,3. lõigu kohaselt panid Mitra ja Varuna lehmad piima andma ja taimed kasvama. Jumalad annavad ka üheskoos vihma (RV I,152,7; III,62,16; V,62,3; V,63,1-6; V,68,5; V,69,2; VI,67,7; VII,62,5; VII,64,2; VII,65,4; VIII,25,5 ja 6). Rgveda X,130. hümni loomisloos on Mitra ja Varuṇa paar seotud virāj värsimõõduga.

Koos tegid Mitra ja Varuṇa Päikesele taevasse tee (RV VII,60,4; VII,63,5) ja seadsid ta taevasse kulgema (RV IV,13,2; V,62,1; V,63,7; VI,67,6). Ilmselt seetõttu jagavad jumalad valgust (RV III,61,7; VII,66,9). Rgveda VII,66,10. värsis kuulub Mitrale, Varuṇale ja Aryamanile ühine epiteet Päikesesilmsed (skr nom. pl. sūracakșasah). Taevajumalad lõid ka aja ja ohvrikalendri: aasta, kuu, päeva ja öö ning ohverduse (RV VII,66,11). Kolmekesi avardavad Mitra, Varuna ja Aryaman ilmamaad (RV VII,60,9; VII,62,6; VII,63,6). Rgveda V,69,1. lõigus hõlmavad Mitra ja Varuṇa kolme valgussfääri, kolme taevast ja kolme taevakaart s.t valitsevad taevast.

Jumalad aitavad lahingus (RV I,152,7; V,62,9; VIII,25,24): nad tapavad vaenlasi (RV V,64,1; V,66,1; V,67,2; V,71,1; VI,24,5; VI,67,4; X,132,2) ja surmavad dasyusid (RV V,70,3). Mitra ja Varuna kaitsevad igasuguste ohtude eest (RV I,23,6; I,41,1 ja 2; I,71,9; I,122,10; I,136,7; I,167,8; II,27,6 ja 7; IV,55,1; V,41,1; V,65,5; V,66,2 ja 6; V,67,3; V,69,3; V,70,3; VI,21,9; VI,67,2; VII,50,1; VII,52,2; VII,64,3; VII,66,5; VIII,25,11 ja 13; VIII,101,4), nende erilise hoole all on "kümne kuninga sõja" võitja Sudās (RV VII,60,8 ja 9). Jumalate paar aitab hädas (RV I,41,3; II,27,5; VII,60,6 ja 12; VII,61,7; VII,66,5). Rgveda VII,65,3. värsi kohaselt viivad jumalad hädadest eemale justkui paat üle vee. Lisaks sellele päästavad Mitra ja Varuna ahistusest (RV I,41,3; I,106,1; I,136,5; V,67,4) ning hoiavad mürgiste putukate eest (RV VII,50,1). R.gveda I,152,2. värsis surmavad Mitra ja Varuṇa vaenlase välgunoolega justkui äikesejumalad.

Mitra ja Varuna tandem jagab rikkusi (RV I,23,6; I,41,2; I,122,8; I,151,5; V,41,1; V,51,14; V,63,2; V,64,6; V,68,3 ja 5; V,69,3; VI,67,11; VII,60,11; VII,62,3; VII,66,8; IX,97,58; X,63,9; X,132,3), kingib jõudu (RV I,2,9; I,122,12; I,136,2; I,151,2; V,64,6; V,65,3; VII,60,11; VII,61,2), toitu (RV V,68,5; V,70,2; VII,66,9) ja järglasi (RV V,69,3; VII,60,8). Ohverdajad saavad veiseid (RV I,151,5; V,41,1; 
VI,67,11) (Rgveda I,122,7. värsis sada lehma) ning hobuseid (RV I,122,8; IV,39,2 ja 5; VI,67,11; VIII,25,23), lahingukaarikuid (RV I,122,8) ja -ratsusid (RV I,122,8; VI,67,11). Jumalad panevad niidud veiste tarvis lopsakat rohtu kasvatama (RV III,62,16; VII,62,5).

Varuna ja Mitra juhivad inimesi (RV I,136,3; V,66,3; V,67,4; VII,64,3), juhatavad neid mööda häid teid (RV VII,62,6; VII,63,6) ja aitavad üle jõe (RV VII,60,7). Rgveda VIII,25,9. värss nimetab jumalusi teerajajaiks. Kiidulauljale kingitakse kindel ja hea kodupaik (RV VI,67,2; VII,64,4; VII,66,3), heaolu (RV IV,39,4; VII,60,11), pikk iga (RV VII,62,5) või koguni surematus (RV V,63,2). Rgveda VII,60,6. lõigu järgi suudavad Mitra ja Varuṇa isegi rumala targaks teha. Jumalad õhutavad inimesi tööle (RV VI,67,3). Rgveda VIII,15,9. värsis ülistab tandem Indrat.

Sagedasti tegutsevad Mitra ja Varuna koos Aryamaniga. Kolmik tapab vaenlasi (RV I,26,4) ja juhib neist eemale (RV I,41,3; X,126,1-7), järgib (RV II,38,9) ja edendab seadusi (RV VI,51,3; VIII,19,35; VIII,83,3), karistab patustajaid (RV I,167,8; VII,60,5; VII,66,13) ja vabastab süüst (RV II,27,2; VII,62,2). Elades taevas (RV I,40,5) valvavad Mitra, Varuṇa ja Aryaman kogu ilma järele (RV VII,51,2; VIII,31,13), juhivad (RV I,90,1; I,136,3) ja kaitsevad inimesi (RV I,41,1 ja 2; I,136,5; V,46,5; V,67,3; VI,50,1; VII,40,2; VII,51,2; VII,59,1; VII,82,10; VII,83,10; VIII,18,3 ja 21; VIII,25,13; VIII,27,17; VIII,67,4; X,61,17; $\mathrm{X}, 126,2$, 4 ja 7). Jumalik kolmik vabastab ahistusest (RV VIII,67,2; X,126,2) ja hädast (RV I,41,3; V,67,4; VII,40,4; VII,59,1; VIII,67,2; VIII,83,3) ning jagab rikkusi (RV I,41,2 ja 6; IV,55,10; VI,50,1; VIII,27,17; VIII,28,2; VIII,83,2 ja 4), valgust (RV VIII,19,16; X,185,3), ruumi (RV VII,62,6; VII,63,6), lapsi (RV I,41,6) ja heaolu (RV I,186,2). Üheskoos joovad Mitra, Varuṇa ja Aryaman somarüübet (RV I,79,3; VIII,94,5; IX,64,24; IX,108,14).

\section{I.2.3. Mitra Atharvavedas}

Mitra funktsioonid Atharvavedas on hõlpsasti summeeritavad, ent võrreldes Rgvedaga pole neis erilisi üllatusi või suurt kõrvalekallet varasemast mütoloogiast. Täheldatav on teatud kalle maa ja ilma valitsemise funktsioonide juurest inimeste abistamise poole.

1. Valitsusvõim:

1.1. Mitra ja Varuṇa õnnistavad kuningat võimletuleku puhul (AV III,4,4; III,22,2; VI,97,2; XIII,1,20);

1.2. Mitra ja Varuṇa kaitsevad seadusi ja mõistavad kohut (AV IV,29,1-2; XVIII,1,7; 33; 36); 
2. Kulgemise korraldamine:

2.1. Mitra seadis Maa paika (AV XIX,19,1);

2.2. Mitra ja Varuna lasevad vihma taevast alla sadada (AV V,19,15; V,24,5; VI,132,5);

2.3. Mitra avab hommikul (Päikesele) ukse, Varuṇa sulgeb selle õhtul (AV IX,3,18);

3. Korravalve:

3.1. Päike on Mitra ja Varuṇa silm, nuhk taevas (AV XIII,2,35; XIII,3,13; XX,107,14; XX,123,2);

4. Kaitse ja abi:

4.1. Mitra ja Varuna kaitsevad vaenlaste eest ja aitavad neid tappa

(AV I,20,2; II,28,2; III,6,2; IV,29,1-2; VI,103,1; VI,125,3; XI,6,2; XI,9,25; XIII,1,31);

4.2. Mitra ja Varuṇa päästavad hädast (AV XIX,44,10);

4.3. Mitra kaitseb inimesi tülide eest (AV II,28,1; III,8,1);

4.4. Mitra ja Varuna annavad rikkusi (AV I,9,1);

4.5. Mitra ja Varuna tõrjuvad kurje vaime (AV I,18,2; VI,32,3);

4.6. Mitra aitab kõhukinnisuse ja kusepeetuse puhul (AV I,3,2);

4.7. Mitra ja Varuna aitavad kopsuhaiguste puhul (AV VI,85,2);

4.8. Mitra ja Varuṇa parandavad silmanägemist (AV VII,30,1);

4.9. Mitra ja Varuna aitavad mürkmadude vastu (AV X,4,16);

4.10. Mitra ja Varuna aitavad poisil täismeheks saada (AV II,28,5);

4.11. Mitra ja Varuna aitavad mehel võita naise armastust (AV III,25,6; VI,89,3);

4.12. Mitra ja Varuna annavad naisele järglasi (AV XIV,1,54);

4.13. Mitra ja Varuṇa seavad seemne emaüsasse (AV V,25,4).

\section{I.2.4. Mitra Yajurvedas}

Yajurveda eri redaktsioonides kirjeldatakse Mitrat kui korra ja harmoonia jumalat, kes liidab inimesi ja edendab sõprust (vt Taittīriya saṃhitā I,8,16,2). Mitra on tõe jumal (Taittīriya saṃhitā I,8,10,2-5; Maitrāyaṇi saṃhitā II,6,6) ja seadmuse (skr dharma) kaitsja (Maitrāyaṇi saṃhitā I,2,11; 20,18; Kāthaka saṃhitā II,12; XVII,16; XXV,10; CXVIII,10). Endiselt on Mitra päeva ja Varuṇa öö jumal (Taittīriya saṃhitā VI,4,8,3). Mitra, Varuṇa ja Aryaman tegutsevad (samuti nagu varasemates tekstides) inimeste kaitsjate ja abimeestena (Taittīriya saṃhitā II,4,8; Kāthaka saṃhitā XI,9; CLV,17; Maitrāyaṇi samhitāa II,4,7; II,44,10; 12). 


\section{I.2.5. Mitra Śatapatha brähmaṇas}

Kui Atharvaveda kaldub tekstide iseloomust (igapäevaelu loitsukogu) lähtuvalt tegema Mitrast (ja Varunast) inimeste päästjaid, ravijaid ja kaitsjaid, siis peamine brāhmaṇa, Śatapatha, kujutab Mitrat ja Varunat pigem taevase kuninglikkuse kandjatena.

Lisaks tavapärastele üleskutsetele, et Mitra ja Varuṇa ohvrist osa võtaksid (ŚB II,4,4,10; 14; 18-19; III,1,4,19; III,9,2,15; IV,2,1,27; IV,2,3,12-13; 15; IV $, 2,5,22 ;$ IV, $6,6,8 ; \mathrm{V}, 3,4,3 ; \mathrm{V}, 5,1,1 ; 6 ; 11 ; \mathrm{V}, 5,2,7 ; \mathrm{VI}, 2,2,39$; VII,2,2,12; IX,5,1,5456 ; XI,4,3,5-7; XII,1,3,16; XIII,5,4,25; 28; XIII,6,2,16), on jumalad suurimas brāhmanas seotud sisse- ja väljahingusega (ŚB III,2,2,13; III,6,1,16; III,8,4,14; V,3,5,34; VIII,4,2,6; XII,4,1,9; XII,9,2,12).

Kõige pikem iseseisev lõik (ŚB IV,1,4) kirjeldab Mitrat tarkuse, tõe (vt ka ŚB V,3,3,8 ja 11) ja preestriameti (vt ka ŚB V,3;2,4-8) kehastusena, seevastu Varuṇa on tahte, elujõu ja aadlivõimu kehastus. Teisal (ŚB XI,4,3,3 ja 11) on Mitra aga sõdalasväe (skr kṣatra) kehastus, samas Varuṇa kehastab kuningavõimu (skr rājatā; rājatva).

Loomulikult on Päike endiselt Mitra ja Varuṇa silm taevas (ŚB III,3,4,24; IV ,3,4,10; V ,2,4,5-6; VII,5,2,27) ning kaks jumalat kaitsevad mehi nii lahingus kui ka tavaelus (ŚB I,3,4,4; II,3,4,37; V,4,1,15-16; VI,5,4,10; 14; XII,6,1,11).

\section{I.2.6. Mitra veedade järgses kirjanduses}

Täpsuse huvides lisatagu, et Mitra ei kao India jumalate panteonist pärast veedade kirjandust mitte kuhugi, tema nimi esineb nii eepilise (4./3. saj eKr 3./4. saj pKr) kui ka klassikalise sanskritikeelse kirjanduse (5.-15. saj) tekstides, enamasti siiski pelgalt jumalate loeteludes (nt Mahābhārata II,7,19; IX,44,5; XIII,1,48; 86,16; XIV,21,4). On pentsik, et nii Mahābhāratas kui ka purāna tekstides (loodi 3.-10. saj) on Mitra sageli seotud väljaheidete ja anusega (vt Mahābhārata XII,301,2; XIV,42,34; Viṣnu purāṇa II,12,33; III,11,8).

Ainus Mitraga seotud lugu on osa kuulsast Purūravase ja Urvaśī legendist ${ }^{6}$ : taevane nümf Urvaśí, jumalate prostituut, on lubanud end üheks ööks Mitrale. Samas ihaldab teda selsamal päeval ka Varuṇa. Et lubatud ööl Mitrale "truuks jääda" laseb Urvaśī Varuṇal oma võlusid nautides anumasse onaneerida. Hiljem kohale saabunud Mitra on säärasest lahendusest šokeeritud ning rahuldab end samuti anumasse, keeldudes Urvaśi kehast. Nümfi saatmine maa peale, Purūravase naiseks on Mitra needuse tulem. Anumasse lastud seemnest sünnivad aga kaks Vana-India kuulsaimat tarka - Vasiștha ja Agastya. Lugu esineb nii "Rāmāyanan" eeposes (loodi 2./1. saj eKr - 1./2. saj pKr; vt VII,56,9-57,5) kui 
ka purāṇa kogumikes (Matsya purāṇa CCI,23; Viṣnu purāṇa I,118; Bhāgavata purāṇa VI,18,5; IX,13,6).

\section{I.2.7. Kokkuvõte}

Mitra ja Varuṇa kohta tuleb tõdeda, et kuigi nad täiendavad teineteist, lisades teineteisele värvi, ei erine nende funktsioonid kuigi palju. Varuṇa on tähtsam, võimukam ja jõulisem kui Mitra. Varuṇa on üksigi see, mis koos Mitraga. Mitra on Varuṇata kõigest solaarse iseloomuga jumal, kes tegutseb inimeste ülevaataja ning kannustajana. Tema vaste Avestas - Mithra - on võimsam, ilmselt omandanud proto-Ahuralt enam funktsioone kui Mitra proto-Varunalt. Funktsioonid on lahutamatud ka seetõttu, et need jumalad on ilmselt koos tegutsenud juba indo-aaria ühise religiooni aegadel, kui mitte varasemalgi ajal. Varuṇa (ja tema kõrval Mitra) on eelkõige maailmakorra kaitsjad, kulgemise valvurid, ülevaatajad. Sellega sarnanevad nad oma Avesta kolleegidega. Varuṇa on tõenäoliselt taevajumal, muistne peajumal. Kuigi uuemad aktiivsed jumalad (eriti Indra) on Varuṇa loomistegevusest eemale tõrjunud, korraldab ta Päikese kulgu, hoiab Taevast ja Maad lahus ning omab vähemaid kosmilisi funktsioone. Mitra ja Varuṇa teavad ja näevad kõike, jälgivad ja valvavad, et säilitada korda, tõde ja õiglust. Kirjelduste poolest meenutab Varuṇa semiitide monoteistlikke jumalaid, eriti israeliitide Jahvet (Mackenzie 1994: 26). Mitra on justkui tema peaingel, kuller või saadik - vastavalt oma nimele vahendaja Taeva ja Maa vahel, lepitaja - sõpruse jumal (Mackenzie 1994: 30; Puhvel 1981: 330). Ühiselt on Mitra ja Varuṇa vannete ja lepingute hoidjad. Mitra ja Varuṇa duaalset ühtsust kinnitab veelgi nende ühine poeg Vasiștha (RV VII,33,10 ja 11) (Vasiștha emaks on nümf Urvaśī) ning nende mõlema kuulumine Ādityate hulka.

\section{Mithra Iraanis}

\section{II.1. Iraani allikad}

Sissejuhatava märkusena olgu öeldud, et Iraani all ei mõisteta järgnevalt mitte ainult Iraani kiltmaad, vaid kõiki alasid, mida on asustanud iraani keeli kõnelevad hõimud, st iraani keelte- ja kultuuriruumi, mis ulatus Väike-Aasiast Kesk-Aasia ja Indiani. Erinevalt eelpool käsitletud india allikatest Mitra kohta on iraani allikaid Mithra kohta oluliselt rohkem ja need on mitmekesisemad. Lisaks tekstidele, mis pärinevad 5./4. sajandist eKr kuni 8./9. sajandini pKr, 
kuuluvad Iraani allikate hulka ka Ahhemeniidide ajastu (6.-4. saj eKr) raidkirjad, varasest Sassaniidide ajajärgust (4.-5. saj pKr) pärinevad reljeefid, mündid ja pitsatitel leiduvad graveeringud, Kušaani riigist pärinevad mündid (valdavalt 1. ja 2. sajandist pKr), raidkirjad ja esemetel leiduvad kujutised ning üks tänapäeva Afganistani alalt pärinev maaling. Mithra kuju iraani usundis on käsitlenud ka mitmed kreeka ja rooma autorid.

\section{II.1.2. Iraani religioossed tekstid}

\section{II.1.2.1. Avesta}

Avesta (sõna tähendus ja etümoloogia ei ole selge ${ }^{7}$ ) on prohvet Zarathustra poolt reformitud muinaspärsia usundi ehk zoroastrismi kanooniliste tekstide korpus. Avesta kolm peaosa on Yasna ('kultus, liturgia'; 72 peatükki, sh Gāthās (=hümnid Yasna 28-34, 41-51, 53)), 21-st hümnist koosnev kogumik Yašt (hümnid on pühendatud erinevatele jumalustele; sõna tähendab 'ohvrit') ja Vendīdād ('Seadus deemonite vastu'). Avesta on kirjutatud muinaspärsia ehk avesta keeles. Et see keel polnud juba Zarathustra-järgsel ajal enam iraanlaste kõnekeel, tekkis vajadus tõlkida "Avesta" ja seletada seda rahvale arusaadavas keeles. Seetõttu kirjutati Sassaniidide dünastia valitsemisajal (224-651 pKr), kui zoroastrism ehk masdaism muutus taas riigiusundiks, keskpärsia ehk pahlavi keeles muistsete pühade tekstide seletusi, mida nimetati zandiks. Sel põhjusel on nende tekstide kogumikke nimetatud ka Zand-Avestaks (Udam 2001: 67-68).

Avesta üksikud osad on raskesti dateeritavad ja pärinevad ilmselt Iraani erinevatest piirkondadest. Praeguse kuju sai Avesta Sassaniidide ajajärgul, kuid tänaseni on säilinud vaid $\mathrm{osa}^{8}$ algsest tekstist, samuti on tekstid teinud läbi suuri muutusi (Udam 2001: 68). Avesta tekstid jagatakse ajaliselt kahte gruppi vanemateks ja nooremateks tekstideks. Esimesse rühma kuuluvad Gāthā hümnid, Yasna Haptayhāiti (Yasna 35-41) ja neli suurt palvet Yasnast (27) (Kellens: http://www.iranicaonline.org/articles/avesta-holy-book; Stausberg 2002: 83-86; teise rühma suurem osa Yasnast, Visprad, Vendīdād, Korda Avesta, Sīrōza ning 24 hümni kogumikust Yašt (Stausberg 2002: 107-115). Avesta vanimaks osaks on Gāth $\bar{a}$ hümnid, mille autorsuse omistab pärimus Zarathustrale. Viimased dateeritakse umbes aastasse $1000 \mathrm{eKr}$ (Kellens: http://www.iranicaonline.org/ articles/avesta-holy-book). Ka vanimad noorematest tekstidest on dateeritud Ahhemeniidide-eelsesse aega, ajavahemikku u 9./8. (?) - 6. saj eKr (Stausberg 2002: 107). Tekstide paigutamine ja redigeerimine ei olnud ilmselt lõpule jõudnud veel ka hilisel Ahhemeniidide perioodil (4. saj eKr) (Stausberg 2002: 
107). Tekstide kirjapanekule eelnes kindlasti nende suulise tradeerimise faas (http://www.iranicaonline.org/articles/avesta-holy-book;_Stausberg 2002: 72).

\section{II.1.2.2. Pahlavikeelne kirjandus}

Lisaks Avestale on oluliseks allikaks Mithra kohta pahlavikeelne (keskpärsiakeelne) religioosne kirjandus, mis pärineb araablaste vallutustele järgnenud sajanditest (valdavalt 9. ja 10. sajandist pKr) (Stausberg 2002: $291 \mathrm{jj}$ ). Mithrat (Mihr) käsitlevad pahlavikeelsetest teostest iseäranis "Dādestān $\overline{1}$ dēnīg" (Religioossed (kohtu)otsused) ja "Zand ī Wahman yasn" (tuntud ka nime all Bahman yašt). Esimene neist, mille autoriks on zoroastristlik õpetlane ja ülempreester Manūščihr, on kogumik vastustest 92 küsimusele, millega zoroastristid olid pöördunud oma kõrgete vaimulike poole. ${ }^{9}$ Teine teos kuulub apokalüptilise kirjanduse hulka ja käsitledeb viimseid sündmusi. Teos on dateeritud 7. sajandi lõppu pKr (Sundermann: http://www.iranicaonline.org/ articles/bahman-yast-middle-persian-apocalyptical-text).

\section{II.1.3. Ahhemeniidide raidkirjad}

Ahhemeniidide (6.-4. saj eKr) raidkirjad, mis on koostatud kiilkirjalises muinaspärsia keeles, mainivad erinevaid iraani jumalaid. Alates Dareios I valitsusajast (522-486 eKr) mainitakse neis kõige sagedamini Auramazdāt (Avesta Ahura Mazdā vaste), kes kannab tiitlit baga vazraka (suur jumal) ning keda kirjeldatakse kui loojat ja kuningavõimule alusepanijat. Alates Artaxerxes II valitsusajast (404-458 eKr) ilmuvad raidkirjadesse ka teised jumalad, nende hulgas ka MiӨra. Kuigi raidkirjad ei anna tema kohta palju informatsiooni, kinnitavad need antiikautorite teateid, mille järgi Mithra oli Ahhemeniidide aegses Pärsias populaarne jumal. Raidkirjadest on mitmeid erinevaid väljaandeid. Nest kõige olulisemad on Lecoq i (Lecoq 1997) ja Schmidti (Schmidt 2009) väljaanded, millele tuginetakse ka käesolevas artiklis.

\section{II.1.4. Kreeka ja rooma autorid}

Alates Kreeka-Pärsia sõdadest (6.-5. saj eKr), mil kreeklased astusid tihedatesse kontaktidesse Pärsiaga ${ }^{10}$ on mitmed kreeka ja hiljem ka rooma autorid toonud ära teateid iraani usundi kohta, mainides neis ka Mithrat. Sellisteks autoriteks on Herodotos (u 484-425 eKr), Xenophon (u 430-354 eKr), Samose Duris (u 340-270 eKr), Ailianos (sünd u $200 \mathrm{eKr}$ ), Strabon (u 64/63 eKr 20 pKr), Plutarchos (46-119 pKr), Curtius Rufus (1. või 2. saj pKr), Cassius 
Dio (u 150-235 pKr) ja Pseudo-Kallisthenes (3. saj. pKr). Nende teated on eriti väärtuslikud seetõttu, et need annavad infot ajajärkude kohta, mille kohta leidub vähe iraani allikaid. Kuigi mõnel juhul (nt Herodotose teate puhul Mithra kohta) võib oletada iraani usundi vääritimõistmist, on antiikautorite pilt iraani usundist üldiselt kooskõlas sellega, mille annavad iraani allikad.

\section{II.1.5. Kušaani riigi mündid ja raidkirjad ning kuningas Kaniška reliikvialaeka kaas}

Kušaani riik asus praeguse Afganistani, Pakistani ja India territooriumil, hõlmates ka piirkondi tänapäeva Tadžikistani, Usbekistani, Türkmenistani, Kõrgõstani ja Kasahstani aladel. ${ }^{11}$ Kuigi riigis elas palju erineva etnilise päritoluga rahvaid ja hõime (sh kreeklasi), oli valitsev etnos, kušaanid, indoeuroopa päritoluga. Kušaani riigis elas erinevaid iraani keeli kõnelenud rahvaid ning seetõttu oli seal paljude erinevate usundite ja kultuste hulgas levinud ka iraani usund. ${ }^{12}$ Seega kuulub ka muistse Kušaani riigi ala iraani kultuuriruumi, mis ulatus pikka aega Väike-Aasiast ${ }^{13}$ ja Kaukaasiast kuni Indiani.

1. ja 2. sajandist pärinevad Kušaani riigi mündid kujutavad erinevaid jumalusi ${ }^{14}$ kelle hulgas on ka Mithra (müntidel esineb tema nimi mitmel kujul:

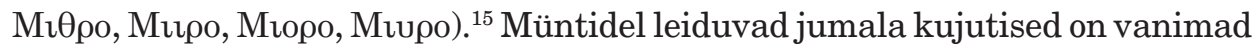
visuaalsed Mithra kujutised iraani kultuuriruumist. Mithrat on kujutatud ka kuningas Kaniška I ${ }^{16}$ reliikvialaekal, mis kujutab kuninglikku investituuri. Selle viivad läbi kaks jumalat, kuujumal Mao ja Mithra (Widengren 1965: 336).

Mithrat mainitakse ka ühes Kušaani riigist pärit baktriakeelses raidkirjas, mis on tuntud Rabātaki raidkirja nime all. See 1993. aastal Rabātakist (praegune Afganistan, Baghlāni provints) leitud ja raskesti dateeritav (Nicholas Sims-Williamsi arvates pärit Kaniška ajastu 6. aastast, mis on tema arvestuse kohaselt a 132-133 pKr (Sims-Williams 2012: 77; http://www.silkroadfoundation. org/newsletter/vol10/SilkRoad_10_2012_simswilliams.pdf)) tekst (read 7-19) nimetab erinevaid jumalusi, keda kuningas Kaniška austas. Nende hulgas on lisaks Nanale, Ummale, Aurmuzdile, Sroshardile ja Narasale nimetatud ka jumal Mihir (st Mithra) (vt ibid.: 78). Carsten Colpe väidab, et Mithrat mainitakse ka Nokonzoko raidkirjas $\left(\mathrm{SK}_{4}\right)$, mis avastati 1957. aastal Surkh (Sork) Kotalist (Põhja-Afganistan) väljakaevatud kuningas Kaniška I templist (Colpe 1983: 851). Sellest Kaniška järglase Huviška I valitsusaja algusesse dateeritud raidkirjast on olemas kolm koopiat - M, A ja B. Koopia A publitseeris esmakordselt André Maricq, koopiad A ja B avalikustas Émile Benveniste. Raidkirjad mainivad pühamu rajamist Kaniška poolt ja räägivad selle taastamisest Huviška valitsusajal. Vastavalt raidkirjale kandis tempel nimetust 
Kanēško oanindo bagolango, mille oletatavaks tõlkeks on pakutud 'Kaniška võidu tempel' (Bivar: http://www.iranicaonline.org/articles/baglan-districtand-town-of-afghanistan). Tempel oli pühendatud samaaegselt nii astraalsele võidujumalusele Oanindole, keda on tiivulise olendina kujutatud ka Kušaani riigi kuldmüntidel, kui ka jumalikustatud kuningale (resp. kuningadünastiale) (ibid.). Helmut Humbach väitis, et raidkirja näol on tegemist Mithrale pühendatud hümniga (Humbach 1960). Raidkiri on raskesti tõlgitav ja tõlgendatav. Toomata siin ära ülevaadet diskussioonist selle tõlgendamise erinevate võimaluste üle (vt selle kohta Henning: https://www.azargoshnasp. net/languages/Sogh/Thebactrianinscription.pdf) olgu öeldud, et käesoleva artikli autorid toetavad Nicholas Sims-Williamsi ja János Harmatta interpretatsiooni, mille järgi jumaluse nimena Mithrat tekstis ei esine - seal leidub vaid kaks teofoorset nime, mille üks komponent on Mihr (Mithra) - Burzmihr ja Mihraman. Viimast nime kandis raidkirja kirjapanija, esimest aga tema isa (Sims-Williams 2012: 78-79 http://www.silkroadfoundation.org/newsletter/ vol10/SilkRoad_10_2012_simswilliams.pdf; Harmatta 1994b: 427-432). Seega nimetatud raidkiri käesoleva artikli autorite meelest allikana Mithra kultuse kohta Kušaani riigis arvesse ei tule.

\section{II.1.6. Kušaani-Sassaniidi mündid}

3. sajandil pKr algas Kušaani riigi langus, mille käigus ühtne impeerium lagunes erinevateks riikideks. Sellele aitas kaasa ka Aasia uue suurvõimu, Pärsia Sassaniidide esilekerkimine. Sassaniidid vallutasid Kušaani riigi tuumikala Baktria, muutes selle oma impeeriumi osaks. Samal ajal lagunesid ka kušaanide valdused Indias (Danielou 2011: 176; Sagar 1992: 176). Neist osa läks kohaliku kuningadünastia Nāgadade kätte, osa liideti Sassaniidide riigiga (ibid.). Sassaniidide poolt rajatud Kušaani-Sassaniidi dünastia müntidel, mis pärinevad 3. sajandi lõpust ja 4. sajandi algusest, leidub Mithra kujutisi, mis erinevad varasematel kušaani müntidel leiduvatest kujutistest.

\section{II.1.7. Hormizd I mündid}

Mithrat on kujutatud ka Sassaniidide valitseja Hormizd I (valitses 272-273 pKr) müntidel. Teadaolevalt on need ainsad Sassaniidide Iraani mündid, millel leidub selle jumala kujutis. 


\section{II.1.8. Tāq-e Bostāni kaljureljeef}

Tāq-e Bostāni kaljureljeefil, mis asub praeguse Kirmanšahi lähedal (Iraanis) ja on dateeritud 4. sajandisse pKr, leidub Mithra kujutis. Reljeefi keskel on kujutatud Sassaniidist kuningat, keda on identifitseeritud erinevalt. Richard Freye ja Michael Stausberg peavad teda Ardašir II-ks (valitses 379-383 pKr) (Freye 1978: 205-211), Franz Grenet seevastu Šāpūr II-ks (valitses 383$388 \mathrm{pKr}$ ). Valitseja jalge all olev kuju on igal juhul Rooma keiser Julianus Apostata (Stausberg 2002: 214; Grenet: http://www.iranicaonline.org/articles/ mithra-2-iconography-in-iran-and-central-asia). Grenet arvab, et reljeef meenutab Šāpūr II võitu Julianus Apostata üle 363. aastal (ibid.). Kummalgi pool valitsejat on kujutatud jumalat, kellest üks on identifitseeritav Mithrana.

\section{II.1.9. Sassaniidide ajastu pitsat Briti Muuseumis}

Ühel Sassaniidide pitsatil, mis asub Briti Muuseumis ja on pärit 4. sajandi lõpust või 5. sajandist, on säilinud Mithra kujutis. Pitsat on dateeritud 4. sajandi lõppu või 5. sajandisse pKr (Grenet: http://www.iranicaonline.org/articles/ mithra-2-iconography-in-iran-and-central-asia).

\section{II.1.10. Bāmīani seisvat Buddhat kujutava skulptuuri}

\section{niši laemaaling}

Üks tuntumaid Mithra visuaalseid kujutisi pärineb Bāmīanist (tänapäeva Afganistan) ja on dateeritud 6. sajandi I poolde pKr. See on osa maalitud kompositsioonist, mis kaunistas kord 38 meetri kõrguse Buddha niši lage Bāmīanis. Kompositsiooni hävitas Taliban 1999. aastal, ennem kui ta hävitas Buddha kujud, kuid tänu fotodele on pilt sellest säilinud (Grenet: http://www. iranicaonline.org/articles/mithra-2-iconography-in-iran-and-central-asia).

\section{II.2. Mithra iraani allikates}

\section{II.2.1. Nimi}

Avestas esineb sõna miӨra niihästi mitmuses kui ainsuses, niihästi meessoost neutraalse nimisõnana kui ka jumala nimena. Viimasel juhul kirjutatakse see tõlgetes suure algustähega. Kuigi sõna etümoloogia ei ole selge (vt I.2.1), on alates Christian Bartholomaest ja Antoine Meillet'st löönud läbi nimisõna tõlkimine 'lepingu, kokkuleppena'. Bartholomae väitel, kes tõlgib mïrat Vert- 
rag, Abmachung, esineb sõnal Avestas vaid üks kord sellest põhitähendusest erinev tähendusvarjund 'religioosne side, kohustus' (sks religiöse Bindung, Verpflichtung) (Bartholomae 1904: 1183). Bartholomae jättis aga selgitamata, millises suhtes on nimisõna miAra jumala nimega. Meillet samastas need kaks ja selgitas, et jumal Mi $\theta$ ras tuleb näha lepingu personifikatsiooni (Meillet 1907: 143-159). Meillet' tõlgendust on toetanud ja kaitsnud Paul Thieme (Thieme 1957; Thieme 2015: 1998-2009), Ilya Gershevitsch (Gershevitsch 1967) ja Jaan Puhvel (Puhvel 1978: 335-355). Ka Herman Lommel peab mïra tõlkimist lepinguks (sks Vertrag) igati põhjendatuks, kuid pakub selle kõrval välja veel teisegi tõlkevaste - truudus (sks Treue), selgitades, et miӨra tähendab lepingutruudust (sks Vertragstreue) (Lommel 1927: 61). Paul Thieme oletab, et arvestades sõnade mitra, mïra ja mihr erinevaid tähendusi, kuid nende etümoloogilist ja tähenduslikku sugulust, on tõenäoline, et sõna tähendus on teinud läbi teatud arengu, tähendades algselt 'lepingut' (sks Vertrag), seejärel 'lepingusidet' (sks Vertragsbindung) ning viimaks 'sõprust' (sks Freundschaft) (Thieme 1975: 21-33). 10. Yašt 116 puhul eeldab Thieme, et siin on vendade vahel sõlmitud ikkagi reaalne leping ja ta seletab, et selle kirjakoha mõte on, et "juhul, kui kahe venna vahel on sõlmitud sõprusleping, on see üheksakümmend korda püham (st siduvam) kui leping, mis oleks sõlmitud võõraga" (ibid.: 25).

Mïra tõlkmist lepinguna on kritiseerinud Friedrich Wolfgang Lenz, Joel Peter Brereton, Ernst Herzfeld ja Hans-Peter Schmidt. Lenz pakub sõna põhitähenduseks 'respekt, vagadus' (sks Respekt, Frömmigkeit) (tähenduses 'toimimine kooskõlas religiooniga'), st seda, mis Bartholomae arvates oli vaid sõna üks kord esinev kõrvaltähendus. Lenz põhjendab seda asjaoludega, et uuspärsia keeles tähendab sõna mihr 'armastust, sõprust' (sks Liebe, Freundschaft), et klassikalises sanskriti keeles tähendab mitra 'sõpra' ning et 10. Yašt 116 öeldakse, et mi $\theta$ ra "kahe venna vahel on üheksakümnekordselt siduv ning isa ja poja vahel sajakordselt siduv", millest Lenz järeldab, et kuna nimetatud kohas kasutatakse sõna mi $\theta r a$ ka sugulussuhete kohta, on tõlkevaste 'leping' ebasobiv (Lenz 1970: 245-255). Viimane argument on kõige veenvam vastuväide mi $\theta$ ra tõlkimisele 'lepinguks' ka J. P. Breretoni arvates, kes pakub alternatiivseks tõlkevasteks 'liitu' (ingl alliance), väites, et see mõiste on sobivam kui 'leping', kuna 'liit' võib hõlmata ka suhteid, mis ei ole vabatahtlikud, kuid on ometi siduvad (Brereton 1981: 27). E. Herzfeld on veendunud, et Avesta sõna mi $\theta r a$ tähendus kattub sisuliselt mitra tähendusega klassikalises sanskriti keeles ning mihri tähendusega uuspärsia keeles. Ta möönab, et kuigi sõnal võib olla mõnes kontekstis tähendus 'leping, tõotus', defineerib ta mi kohustust, millele on rajatud ühiskond" ning viitab selle kinnituseks eelpool osundatud kirjakohale 10. Yašt, 116-117 (Herzfeld 1947: 467). H.-P. Schmidt peab mi $\theta r a$ tõlkevastet 'leping' liiga kitsaks ning pakub selle asemel tõlkevastet 'liit' (ingl alliance): 
Mõiste mïra kasutamine lojaalsussuhete kohta on [---] lähedaselt suguluses spetsiaalse iraanipärase arenguga. Indias säilis selge vahetegemine veresuhete ja mitra vahel ka veedade-järgsel ajal. Iraani areng oleks raskesti seletatav, kui me eeldaksime, et "leping" oli sõna põhitähendus. See [areng - J. L.] on siiski seletatav tähenduse põhjal "liit". Võttes arvesse kaalutlust, et Rigveedas viitab mitra enamasti liitudele kahe hõimu vahel, on see rahumeelsete suhete kujundamise eesmärk või seda tarvitatakse ühiste vaenlaste vastu - tähendust "liit" võiks pidada lähtepunktiks. "Liit" eeldab vastastikust truudust või partnerite "lojaalsust" ja see tähendusvarjund oli sõnale mitra omane (Schmidt 1978: 385).

Sel kombel saab Schmidti meelest mõistet miAra kasutada kõigi lojaalsust ja truudust eeldavate suhete, ka lähedaste sugulussuhete kohta, mis ideaalis eeldavad samuti lojaalsust, ilma et peaks Thieme kombel oletama, et sugulased (nt isa ja poeg) on sõlminud erilise juriidilise lepingu. Tähendus 'leping' on Schmidti arvates sekundaarne ja tuletatud 'liidust' (ibid.: 386).

Käesolevate ridade autorid on seisukohal, et vaatamata eelpool nimetatud kriitikale on Avesta sõna mïra kõige kohasem tõlkida 'kokkuleppeks' või 'lepinguks'. Vaid üksikutel juhtudel (nagu näit 10. Yašt 116) võiks sõna tõlkida teisiti, näiteks 'truuduseks' või 'ustavuseks'. Enamasti on miӨra siiski truudus või ustavus sõlmitud lepingule või antud vandele ning MiӨra (suure algustähega) on muinaspärsia jumal, kellest usuti, et ta valvab lepingutest/kokkulepetest/ tõotustest kinnipidamise järele.

\section{II.2.2. Mithra Avestas}

Avestas on Mithrat (MiӨra) mainitud kokku 170 korral, neist 120 korda spetsiaalselt talle pühendatud hümnis, 10. Yaštis (Jafarey 1975: 55). MiӨra, Anāhitā jpt populaarsed iraani jumalad puuduvad vanemates,${ }^{17}$ ent ilmuvad nähtavale nooremates Avesta tekstides (Stausberg 2002: 115). Viimastes ei ole Zarathustra vestluspartneriks mitte üksnes Ahura Mazdā, vaid ka teised jumalad - VərəӨrayna, Anāhitājt (ibid.: 35). MiӨra puudumist Avesta vanemates kihistustes, eriti Zarahustrale enesele omistatud "Gāthā" hümnides ja "Yasna Haptanhāiti" nime all tuntud tekstikorpuses, mille autorsus on omistatud samuti Zarathustrale (Kellens: http://www.iranicaonline.org/articles/avesta-holybook), on seletatud Zarathustra religioonireformiga - prohvet olevat loobunud varasematest jumalatest Ahura Mazdā kasuks. Eriti kaugele läheb selle suunas Lommel, kes väidab, et Zarathustral olevat olnud eriline vastumeelsus MiӨra suhtes, kuna too olevat tapnud härja, ent Zarathustra olevat olnud igasuguste vereohvrite vastu (Lommel 1944-1949: 207-218; Lommel 1962: 360-373; 
Lommel 1964:161 jj). Siiski ei kõnele MiӨra härjatapmisest ükski iraani tekst härjatapjaks saab alles Mithras Rooma keisririigi aegsetes müsteeriumites, mille olemasolu ei ole tõestatav enne 1. sajandit pKr (Clauss 2012: 27-28). Varasel islami perioodil kirja pandud pahlavikeelses eshatoloogilises tekstis "Bundahišn" on jumal Ohrmazdi loodud ürghärja (Gāw $\bar{\imath} \bar{E} w d \bar{a} d$ ) tapja kuri vaim Ahriman (ptk 4). "Bundahišnis" jutustatakse veel teisestki härjaohvrist. Viimsel päeval saabub lunastaja (saošyant), kes äratab üles surnud. Lunastaja toob koos oma abilistega ohvri. Ta ohverdab härg Hadayani, kelle üdist ja valgest haoma taimest tehtud jooki antakse juua ülesäratatud surnutele. Kui nad seda joovad, muutuvad nad surematuteks. Seega pole härja tapjaks siingi MiӨra. Lommel üritas tõestada MiӨra härjaohvri pärinemist indoiraani ajastust, viidates ühes brāhmaṇas leiduvale pärimusele, mille järgi mingi jumal tapab Soma (Avesta Haoma) härja kujul. Samas ei viita aga miski sellele, et see jumal oli MiӨra. Kuigi mitmed Rooma riigis levinud Mithrase kultuse uurijad võtsid Lommeli hüpoteesi omaks (Vermaseren 1963: 17; Merkelbach 1994: 13jj), näitas iranist Ilya Gershevitch veenvalt selle paikapidamatust (Gershevitsch 1967: 64; Gershevitsch 1975: 68-89). Isegi teaduses laialt levinud seisukoht, et Zarathustra keelustas loomohvrid (Lommel 1930: 207-218; Nyberg 1966: 51, 71; Widengren 1965: 66; Merkelbach 1994: 10), ei ole leidnud paljude uurijate toetust. Nii arvavad näiteks Robert Zaehner (Zaehner 1961: 84 jj), Jacques Duchesne-Guillemin (Duchesne-Guillemin 1962: 99 jj) ja Mary Boyce (Boyce 1975a: 217), et Zarathustra ei mõistnud hukka vereohvrit kui sellist, vaid üksnes loomadele liigsete kannatuste põhjustamist ohverdamisel. Nõustuda ei saa ka laialt levinud seisukohaga, nagu oleks MiӨra Zarathustra reformiga iraani usundist pikemaks ajaks täielikult kadunud (vt ka Thieme 2015: 2006-2007).

Zarathustra õpetuse järgi lõi Ahura Mazdā kuus jumalust ("teised ahurad"), kes on Ahura Mazdā emanatsioonid. Zoroastrismis tuntakse neid yazatade ("kummardamisväärsed") nime all. Nende hulka kuulub ka MiӨra. Nende jumalike olendite kohta kasutatakse zoroastrismis ka nimetust Aməša Spəntas (pühad surematud) (Boyce 1979: 21). G. Dumézil peab kõiki jumalikke entiteete, keda hiljem hakati tähistama nimetusega Aməša Spəntas, "paganlike", st zoroastrismieelsete jumalate asendajateks: Vohu Manah (Hea mõtlemine $)=$ MiӨra; Aša (Tõde) = Varuna; Xšära (Valitsus) = Indra; Ārmaiti (Pühendumine) $=$ Sarasvatī; Hauruuatāt ja Amərətatāt (Tervis ja Surematus) = Aśvin’id (Nāsatya'd) (Dumézil 1945). Tema seisukoha on omaks võtnud Jacques Duchesne-Guillemin (Duchesne-Guillemin 1962: 201) ja Geo Widengren (Widengren 1965: 200). Teisiti seletab Ahura Mazdā ja MiӨra ning teiste jumalate suhet Zarathustra religioonis Mary Boyce, kes väidab, et indoiraani traditsioonis võis preester pühendada hümni üksikule jumalusele, mainides selles ainult selliseid jumalusi, kes on tolle üksiku jumalusega lähedalt seotud, mis ei tähenda teiste 
jumalate hülgamist. Samuti olevat Zarathustra pühendanud oma hümnid suurele jumalale Ahura Mazdāle, mainides tema kõrval entiteete, kes on temaga lähedaselt seotud. Tegelikult olid need entiteedid aga teised iraani jumalad (Boyce 1969: 10-34). Hiljem tõlgendas Boyce (Boyce 1992: 56) Gāthādes esinevat väljendit mazdåscā ahurånhō (Mazdā ja (teised) ahurad) (Yt 30.9, 31.4) viitena Ahura Mazdāle, MiOrale ja Apąm Napātile (Boyce 1992: 56). Üldiselt tõlgendatakse väljendit Ahura Mazdā ja Aməša Spəntadena. Sellist tõlgendust toetab ka Hans-Peter Schimdt, kes juhib tähelepanu seigale, et Aməša Spəntasid pole kunagi nimetatud ahuradeks ja juhul kui Boyce'il oleks õigus, oleks eeldatav duaali, mitte mitmuse vormi kasutamine (Schmidt: http://www.iranicaonline. org/articles/mithra-i.).

\section{II.2.2.1. MiӨra 10. Yaštis}

10. Yašt ehk Mihr-Yašt, mis on täielikult pühendatud jumal MiӨrale, on pärit Ahhemeniidide ajajärgust, kuid selle täpsema dateeringu suhtes on erinevad seisukohad: Jaime Alvar dateerib teksti 5. sajandisse eKr (Alvar 2008: 80-81), Ilya Gerschevitsch täpsemalt 5. sajandi II poolde (Gerschevitsch 1967: 3), Gherardo Gnoli aga 5. või 4. sajandisse eKr (Gnoli 1979: 725-740). Richard Gordoni hinnangul pärineb 5. või 4. sajandist eKr hümni praegune kuju, kuid ta on veendunud, et hümn sisaldab ka varasemast ajast pärit ainest (Gordon 2012: 967). Raskesti dateeritavad on aga kõik Avesta tekstid (Burkert 2004: 111-113).

Avesta hümn MiӨrale algab Ahura Mazdā avaldusega, et ta lõi MiӨra ja tegi ta kummardamise ning palvete vääriliseks, nagu ta on ise (Yt 10.1). Mihr-Yašti järgi on MiӨra suur ja võimas jumal - yazata ('kummardamisväärne', 10.5) ${ }^{18}$ ning teda austatakse kummardustega (nəmah, 10.6). Nagu Ahura Mazdā, nii kannab temagi tiitlit ahura ('isand'; 10.25; 69) ning paljudel juhtudel käsitatakse neid võrdsetena (Thieme 2015: 2000). Lähtudes oma nime tähendusest (vt 2.1.), on MiӨra seotud lepinguliste suhetega või nagu ütleb M. Boyce, kehastab ta ustavust lepingule (Boyce 1979: 10). Laiemalt on ta seotud aga ka selliste sotsiaalsete sidemetega, nagu sõprus, abielu, veresugulus (10.116), mistõttu Hernrik Samuel Nyberg iseloomustab MiӨrat kui "eeskätt sotsiaalset jumalat" (Nyberg 1966: 60; vrdl ka Alvar 2008: 79). Kõige laiemalt võttes on

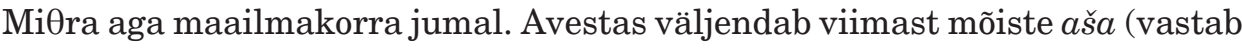
muinaspärsia mõistele arta ja veedade mõistele r $r$ ta). See on kosmiline kord, mis hõlmab nii loodust kui ka sotsiaalset ja religioosset elu. ${ }^{19}$ Mithra on jumal, kes juhib inimesi "korra ( $a s ̌ a)$ teerajal" (10.86).

Juba üsna hümni alguses esitatakse üleskutse mitte rikkuda lepingut, ükskõik, kas see on sõlmitud petliku inimese või "hea religiooni" ausa järgijaga leping on mõlemale kehtiv (10.2). Hümnis domineerib leping maade vahel. MiӨra valvab lepingutest kinni pidamise järele ning karistab lepingurikkujaid ja 
petiseid (10.1-2.18). Ta teeb teoks suuri ja kohutavaid õnnetusi: kisub tükkideks maju, külasid ja hõime; purustab kolpasid, segab maa peal konte, juukseid, ajusid ja verd, hävitab terveid maid (18; 26, 72). Ta röövib jõu kätest, tugevuse jalgadest, valguse silmist ja kuulmise kõrvust neil, kes teda petavad (10.23; eriti 49). Nende nooled, odad, lingukivid, noad ja sõjanuiad, kes vihastavad MiӨrat, muutuvad võimetuks (10.39-40). Aga ta jagab ka suuri ja imelisi õnnistusi ning temast näivad sõltuvat kõik fundamentaalsed elu ja heaolu tingimused. Tema läbi langevad (mägedest ja taevast) alla veed; tema läbi kasvavad taimed; ta annab järeltulijaid kariloomadele ja järglasi (poegi ja/või teenreid) inimestele; ta annab kiireid hobuseid ja "laiu loomade karjamaid" (Thieme 2015: 2000).

MiӨra õnnistused ja hädad on välja jagatud range põhimõtte järgi. Yašt ei väsi kordamast (seda punkti rõhutatakse tõepoolest peaaegu igas salmis): Mithra õnnistused on neile, kes ei murra oma lepingus antud sõna, tema karistused aga neile, kes seda teevad (mïradruj-), kes võitlevad oma lepingupartnerite (auuimi $\theta r i$-) vastu ega tunnusta piduliku tõotuse (auruaa $\theta \mathrm{a}-$ ) pühadust. MiӨra saadab õnnistused tasuna, onnnetused aga karistusena praktilise, ühiskondliku või poliitilise käitumise eest. Isegi kui ta karistused tunduvad liialdatuna, on nad ranges vastavuses toimepandud kuriteoga: ta karistab "viiekümne tapmist sadade tapmistega, saja tapmist tuhandete tapmistega, tuhande tapmist kümne tuhande tapmisega, kümne tuhande tapmist loendamatute tapmistega" (43) (Thieme 2015: 2000-2001).

Et täide viia oma funktsiooni kaitsta lepingute pühadust, peavad lepingu jumalal olema teatud omadused ja jõud. Ta peab olema ärgas ja koguni kõiketeadev, et avastada kohe iga lepingurikkumist. Tal peab olema väge õnnistada neid, kes peavad oma lepinguid, ja jõudu karistada neid, kes ei pea neist kinni. Poeetiline kujutlusvõime muudab need abstraktsed postulaadid konkreetseteks, sageli maalilisteks väideteks. MiӨra on ärgas (jagauruuah-) või täpsemalt 'ilma uneta' (axvafna-). MiӨra on "kogu loodu, kogu maa" $(54,103)$ vaatleja (54) ja valvur (54). Konkreetsemalt: "ta valvab kogu aarialaste maad [---] kõike, mis on taeva ja maa vahel" (13, 95). Piltlikumalt: "tal on avar silmapiir" (7 jm), "ta vaatab alla kõrgelt Harā mäelt isegi veel enne, kui päike tõuseb, [---] tema eluase on Hara mäel, kust ta vaatleb kogu kehalist elu" (13; 50 jj). MiӨra on kõigeteadja (vispo-viduuah-). Konkreetsemalt ja piltlikumalt: "tal on kümme tuhat silma", "tuhat kõrva"; "tal on kümme tuhat salakuulajat". Ta on kõikjal: "tema asukoht on selle maa hingus", ta on ise "see hingus" (44; 95). MiӨral on väge lüüa ja karistada seda, kes "oma lepinguid esimesena reedab" (45), see tähendab neid, kes esimesena murravad lepingut, sundides seeläbi partnerit murdma oma lepingutõotust; nad on need, kes "reedavad oma lepingu/lepingus antud sõna" (mi $\operatorname{radruj-),~kes~"võitlevad~oma~lepingupartneriga"~(auuimi\theta ri-,~}$

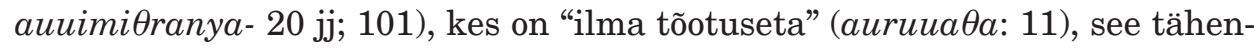


dab, "kes ei tunnusta piduliku lubaduse pühadust". Ta osaleb lahinguväljal kui kaarikuvõitleja (raaӨešta), hoides käes muinasjutuliste omadustega sõjanuia (vazra-): “Ta lõikab kõik tükkideks, lepingumurdja sureliku kondid ja juuksed ja ajud ja veri segunevad maapinnal" (12); "Seejärel viskab ta nad alla, tema, MiӨra ("Leping"), kellel on avarad veiste karjamaad - tappes sadasid viiekümne tapmise pärast, tuhandeid saja tapmise pärast [---], kui ta on raevunud, vihale aetud" (41). Kuivõrd püha leping ( $m i \theta r a$ ) või pigem "lepingu jumal" kehtestab piirid (karšo-razah-, 61), annab MiӨra rahuliku elu, mis on "hea elu" (4), annab karja ja inimesi $(65 ; 28)$ ning sellega kaasnevaid rikkusi (78). Ta on "veiste karjamaade avarus/laius" (vouru-gaoyaoti-), see tähendab, ta annab laiad karjamaad, kus karjal on vabalt ruumi isegi kaugel kaitsvast asustusest, ilma et peaks kartma reetlikke kallaletunge või röövimisi (Thieme 2015: 2002-2005). MiӨra võitleb ka deemonitega - ta purustab tema ees hirmu tundvate (10.97, 99) deemonite (daēuua, 10.26) pead ja ta on üleloomulike nõidade (pairikā, 10.26) vaenlane.

MiӨra on seotud tule ja päikesega. Kuna Pärsias oli tavaks pitseerida lepinguid tule juures, seostub Mithra tulega (10.127). Pole ilmselt juhus seegi, et tema kaaslaste hulka kuulub ka tulejumal Ātar (10.3). MiOra seost tulega võib järeldada ka hilisemate iraani ja kreeka-rooma allikate, eriti neis mainitud tuleordaali põhjal, mida kasutati vande puhul tõe kindlakstegemiseks (Boyce 1975b: 69-76; Boyce 1975a: 35). Mary Boyce oletab, et MiӨra seosest tulega tulenes ka tema seos päikese kui taevase tulega (Boyce 1975a: 28).

Kuigi juba Ch. Bartholomae väitis, et MiӨra oli aarialaste päikesejumal (Bartholomae 1904: 1183) ning ka L. Gray (Gray 1929: 96 jj)20 ja H. Lommel (Lommel 1962: 360-373) olid veendunud, et Avesta MiӨra on päikesega identne, loobus sellest ideest juba A. Meillet (Meillet 1907: 143-159) ning I. Gerschevitsch näitas veenvalt selle paikapidamatust (Gerschevitsch 1975: 68-89). MiӨrale pühendatud 10. Yaštis räägitakse küll sellest, et MiӨra on jumal, kelle üherattalist kuldse rattaga kaarikut ${ }^{21}$ veavad valged hobused, mis on vaieldamatult päikesevankrit kujutav pilt ning annab tunnistust MiӨra ja päikese tihedast seosest, kuid mitte nende samasusest. MiӨra seos päikesega on hümnis selgesti määratletud (10.13): ta on esimene vaimsetest jumalatest, kes tõuseb Harā mäeaheliku kohale ennem kui kiire hobusega surematu päike (Schmidt: http://www.iranicaonline.org/articles/mithra-i). Nii M. Boyce (Boyce 1979: 41) kui ka M. Stausberg (Stausberg 2002: 111) juhivad tähelepanu tõigale, et Avestas eksisteerib eraldi päikesejumal, kes ei ole MiӨra, vaid Hvar (muinaspärsia k 'päike'). Viimane esineb paaris kuujumal Māhiga. Nii nimetab Avestas leiduv jumalate kataloog Sīrōza eraldi kuu- (Māh) ja päikesejumalat (Hvar) ning MiӨrat (16. kohal). Ka Yasna 2.11 nimetatakse MiӨra selgesti päikesest eristatuna. Nimetatud allikate andmeid toetavad antiikautorite teated Ahhe- 
meniidide ajastu kohta, mis näitavad, et päikest ja Mithrat käsitleti erinevate suurustena (vt 2.5).

Viimaks olgu nimetatud veel kaks olulist aspekti, mida 10. Yašt Mithra puhul esile tõstab - MiӨra on maade valitseja ja sõjajumal. Yašt 10.78, 99 öeldakse selgelt, et ta on maaisand ja 10.145 , et ta on kõikide maade maaisand. ${ }^{22}$ Aga ta on ka sõdalane, kes sõidab sõjavankris. Tema peamine relv on sõjanui (10.96, 132), kuid ta kasutab ka nooli, odasid, kirveid ja nuge (10.102, 129-30). Avesta MiӨrat saadab VerəӨrayna, võidujumal, kes tapab vaenlasi (10.70-72; vrdl 127). Ta teeb seda oma metsseakujulises ilmumisvormis, lüües oma vastase pikali ning purustades ta selgroolülid. Ta lõikab kõik tükkideks ning segab kondid, juuksed ja vere (10.72; vrdl 127). G. Widengren oletab, et Mithra oli seotud muistsete iraani hõimude sõjaliste meesteliitudega (Widengren 1965: 24). Juba varem oli sama hüpoteesi esindanud S. Wikander (Wikander 1938). Ka Paul Thieme arvates on MiӨra ainult meeste jumal - lepingud, mille üle valvab MiӨra, näivad Avestas olevat eranditult lepingud meeste (116) või meesterühmade vahel (Thieme 2015: 2001-2002). On tähelepanuväärne paralleel, et ka Rooma keisririigis levinud Mithrase kultus oli reserveeritud üksnes meestele. Ka Rooma Mithrase kultuses on täheldatud jooni, mis meenutavad arhailisi meesteliite (Widengren 1965: 224).

Viimaks olgu nimetatud, et 10. Yaštis kohtab ka vormelit MiOra-Ahura (10. 113. 145), mida on üldiselt mõistetud kui viidet MiӨrale ja Ahura Mazdāle (Schmidt: http://www.iranicaonline.org/articles/mithra-i.). See on paralleel veedades leiduvale vormelile Mitra-Varuna (Widengren 1965: 14; Dumézil 1988) ning pärineb kindlasti zoroastrismile eelnenud ajast.

\section{II.2.2.2. Mithra teistes Avesta tekstides}

Ka teistes Avesta tekstides leidub väiteid MiӨra kohta, mis täiendavad ja kinnitavad 10. Yaštis visandatud pilti. Teose "Vendīdād" sissejuhatuses, kus mainitakse erinevaid jumalikke olendeid, esineb ka MiӨra, kelle kohta öeldakse, et tal on avarad rohumaad (Yasna 1.8; 17.2; 68.22). "Vendīdād" 19, 27 jj kirjeldatakse surmajärgset kohtumõistmist hinge üle. Kohtumõistjateks on siin MiӨra, Zurvan ja Vohu Manah. Yasna 2.11; 4.16; 6.10; 17.10; 22.13 järgi on MiӨra "kõigi maade maaisand". Yasna 2.11; 4.16; 7.13; 17.10; 22.13 esineb juba eespool nimetatud vormel "Ahura (ja) MiӨra". Yasna 17.2 öeldakse, et MiӨra on "tuhande kõrvaga" ja "kümne tuhande silmaga" yazata. Teoses "Visprad" kasutatakse MiӨra kohta taas tiitlit "see, kellel on avarad rohumaad" (7.2). Sama tiitel kordub ka teoses "Xvaršet Nyayišn" (5), kus MiӨrat nimetakse taas "kõigi maade maaisandaks" (7); tema kohta öeldakse veel, et ta on kõige säravam vaimsetest yazatadest, kelle Ahura Mazdā on teinud (ibid.). Ka 
siin kohtab vormelit "MiӨra (ja) Ahura" (ibid.). Kordub ka väide, et MiӨra on "tuhande kõrvaga" ja "kümne tuhande silmaga" (15) ning tiitel "see, kellel on avarad rohumaad" (ibid.). MiOrale pühendatud 2. Nyayaišn (Mihr Nyayišn) kordab samuti paljusid eelnevaid väiteid ja tiitleid, kuid lisab neile mõned, mida eelnevates tekstides ei leidunud. Teoses öeldakse, et MiӨra on see, kellel on avarad rohumaad $(10 ; 13 ; 14 ; 17)$; ta on tuhande kõrvaga ja kümne tuhande silmaga (10); "kõikide maade maaisand" (12); "võimas yazata, kes on kõige võimsam loodud olenditest" (15). 1. Gahis (Havan Gah) on taas mainitud MiOrat kui seda, "kellel on avarad rohumaad" (7). Seda tiitlit kannab ta ka 2. Yaštis ehk Amahraspand Yaštis (4; 9) ja 8. Yaštis ehk Tištr Yaštis (7), kus esineb ka väide, et MiӨra on ümber Tištrya rajanud teeraja (ibid.), st ilmselt siis teeraja, mida mööda see jumalikustatud taevakeha saab liikuda. Samas tekstis väidetakse teises kohas (38), et selle teeraja rajas MiӨra koos Ahura Mazdāga ja et mõlemad liiguvad Tištrya järel, teda saates. 19. Yaštis esineb MiӨra taas kui "kõikide maade maaisand" ja see, "kellel on avaraid rohumaid" (35). Ka siin nimetatakse teda selleks, kellel on "terav kuulmine" (ibid.).

\section{II.2.3. Mithra pahlavikeelses kirjanduses}

MiOra kuju esineb ka Avestale järgnevast ajast pärinevas pahlavikeelses kirjanduses. Siin esineb tema nimi vormis Mihr. Pahlavikeelses kirjanduses arendatakse edasi MiOrale juba Avestas omistatud rolle ja funktsioone. Nii esineb ta näiteks teoses "Dādestān $\overline{1}$ dēnīg" kohtumõistjana surnu hinge üle $(30,10) .{ }^{23}$ Erinevalt teosest "Vendīdād" on siin lisaks Mihrile kohtumõistjateks veel Ohmazd (= Ahura Mazdā), Wahman (= Vohu Manah), Srōs (= Sraoša) ja Rašan (= Rašnu). Hilistes apokalüptilistes tekstides, mille kirjapanek langeb juba islami ajajärku, võib esineda Mihr ka võitlejana kurjuse jõudude vastu apokalüptilises sõjas. Nii astub ta üles näiteks teostes "Bahman yašt" (7, 31-36) ja "Jāmāsp Nāmag" (Jamaspi lugu) (77). Erinevalt varasematest tekstidest on neis teostes asetatud Mihri võitlus deemonitega (mida oli mainitud juba eelpool käsitletud Mihr Yaštis) maailma ajalugu perioodideks jagava apokalüptilise maailmapildi raamesse. Varasemates tekstides veel sellist maailma- ja ajalookäsitlust ei esine.

\section{II.2.4. Mithra Ahhemeniidide raidkirjades}

Vanimates Ahhemeniidide raidkirjades Mithrat ei mainita - neis esineb üksnes Auramazdā kui looja ja õnnetooja; teda peetakse ka kuningavõimu rajajaks. ${ }^{24}$ Esmakordselt ilmub Mithra alles Artaxerxes II (404-359 eKr) raidkirjades 
Susast ja Ekbatanast, kus teda mainitakse kõrvuti Auramazdā ja Anāhitāga kuninga kaitsjatega. ${ }^{25} \mathrm{M}$. Boyce ütleb, et kui varasemad Ahhemeniidide kuningad olid austanud vaid Auramazdāt, murdis Artaxerxes II traditsiooni, hakates lisaks Auramazdāle appi hüüdma Anāhitāt ja Mithrat (Boyce 1979: 61). G. Widengreni arvates saab seda seletada varem austatud, kuid Auramazdā poolt kõrvale tõrjutud jumaluste tagasipöördumisena zoroastrismi (Widengren 1965). Auramazdā, Anāhitā ja Mithra esinevad koos ka Artaxerxes II järeltulija, Artaxerxes III (359-338 eKr) raidkirjades. Jumalad võivad esineda erinevates kombinatsioonides: ühes Artaxerxes II raidkirjas ( $\mathrm{A}^{2} \mathrm{Hb}$ ) esineb Mithra üksinda, ühes Artaxerxes III raidkirjas ( $\mathrm{A}^{3} \mathrm{~Pa}$ 24-26) esinevad aga kõrvuti Auramazdā ja Mithra. Mithral on neis raidkirjades eeskätt kaitsejumala funktsioon - raidkirjas $\mathrm{A}^{2} \mathrm{Hb}$ palub kuningas temalt kaitset endale ("Mithra, kaitse mind!"), raidkirjas $\mathrm{A}^{3} \mathrm{~Pa} 24-26$ aga endale, oma rajatistele ja maale (rahvale).

\section{II.2.5. Mithra kreeka-rooma autorite kirjutistes}

Kreeka-rooma autorite teostes esineb jumala nimi vormis Mithras või Mithres. Esimese kreeka autorina mainib teda Herodotos, kes kirjeldab oma teose "Historia” I raamatus pärslaste uskumusi. Ta väidab, et pärslased ei valmistanud jumalakujusid (mida Ahhemeniidide ajastust ei ole tõepoolest leitud), ent teeb sellest julge järelduse, et pärslased ei uskunud, et jumalad on inimesekujulised, nagu uskusid kreeklased (Hist I 131). ${ }^{26} \mathrm{Zeusi}^{27}$ olevat pärslased samastanud kogu taevalaotusega (ibid.). Teiste pärslaste jumalatena nimetab Herodotos päikest, kuud, maad, tuld, vett ja tuuli (ibid.). Lisaks sellele teatab ta, et pärslased on õppinud assüürlastelt ja araablastelt Urania austamist. Tegemist on jumalannaga, keda assüürlased nimetavat Mylitta, araablased Alilat, pärlased aga Mithra (ibid.).

On üpris kindel, et taevaga samastatud Zeusi puhul on tegemist zoroastristliku peajumala Ahura Mazdāga. Päikese ja kuu käsitlemine omaette jumalatena on kooskõlas Avesta traditsiooniga (vrd Hvar ja Māh Avestas). Maad, tuld ja vett võib samastada Ahura Mazdā kaaskonda kuuluvate jumaluste Ārmaiti, Aša Vašista ja Haurvatatiga, kes on kolm Ameša Spenta ("pühad surematud”) liiget. ${ }^{28}$ Mithra ja päikese eristamine on samuti kooskõlas Avesta traditsiooniga, mida kinnitavad ka järgneva aja kreeka autorid, ent ebatavaline on Mithra käsitamine naisjumalana. Kõige lihtsam oleks seda seletada lihtsalt Herodotose-poolse vääritimõistmisena, ent Richard Gordon oletab, et Mithra on siin äravahetatud päikese eel ilmuva Koidutähega, st planeet Veenusega (Gordon 2000: 287).

Paljud kreeka autorid kõnelevad vandeandmisest Mithra nimel. Nii teatab Xenophon teoses "Kyroupaideia”, et pärsia ülik Artabazos vandus Mithra nimel 
(Cyroupaid VI 5, 53). Sama autori teoses “Oikonomikos" vannub ka kuningas Kyros Mithra nimel (Oeconom IV, 24). Plutarchose "Paralleelsete elulugude“ hulka kuuluva Aleksander Suure eluloo järgi vannutas viimane Ahhemeniidide kuningas Dareios III oma kammerteenrit mõtlema Mithrale ja rääkima tõtt (Alexander: 30). Ka Aelianus ${ }^{29}$ ja Pseudo-Kallisthenes ${ }^{30}$ teatavad, et pärslased andsid vandeid Mithra nimel. Rooma ajaloolane Curtius Rufus seostab Mithrat seevastu sõjalise julguse ja jõuga. Ta teatab, et Dareios III pöördus enne Gaugamela lahingut päikese, Mithra ja (igavese) tule poole, et need annaksid ta sõjaväele julgust (Historia Alex. IV, 13, 12). Oluline on see teade veel sellegi poolest, et Mithra ja päike on selle järgi erinevad jumalused.

Kuigi paljud antiikautorid teatavad, et pärslased austasid päikest, ${ }^{31}$ pärineb esimene teade päikese ja Mithra identsusest geograaf Strabonilt, kes ütleb, et pärslased nimetavad päikest (Heliost) Mithreseks (Geographica, XV, 3, 13 p. 732 C). Ajaliselt järgnevad andmed, mis kinnitavad Mithra ja päikese identsust, on pärit hilisest hellenismiajastu allikatest ning nendeks on Kommagene kuningas Antiochos I (valitses u 70-35 eKr) valitsusajast pärinevad kiirtepärjaga Mithra kujutised Väike-Aasiast ${ }^{32}$ ning Kušaani riigi mündid (vt 2.6). Allikate põhjal jääb mulje, et Mithrat hakati päikesega samastama ajajärgul, mis kattub Iraani ajaloos Aršakiidide valitsusajaga (250 eKr - $224 \mathrm{pKr}$ ). See on kooskõlas ka keeleajaloo andmetega - sõna mihr tuleb 'päikese' tähenduses kasutusele Partia perioodil (Frye 2015: 2019).

Viimaks olgu mainitud, et antiikautorid on pärandanud meile ka teateid Mithra kohta, mis ei anna meile Mithra mõistmiseks iraani religioonis mingit olulist informatsiooni, ent iseloomustavad Mithra retseptsiooni antiikkultuuris. Nii teatab näiteks satiirik Samosata Lukianos, et Mithra on jumalate seas uustulnuk Meediast, kes ei mõista kreeka keelt (Deor. conc. 9). See satiiri kontekstis esitatud teade ei kajasta aga midagi muud, kui teadmist, et Mithra, keda austasid 2. sajandil ka kreeklased ja roomlased, on võõras Iraani algupäraga jumalus. Samas ei tõesta see teade Rooma keisririigi-aegse Mithra kultuse Iraani päritolu. ${ }^{33}$ Sama kehtib ka uusplatoonik Porpyhriose teate kohta, et esimene, kes püstitas pühamu maailma loojale (sic!) Mithrale, oli Zoroaster. Ta olevat kujundanud ühe loodusliku koopa Iraani mägismaal Mithra pühamuks, mis olevat kosmose võrdpilt (De antro nympharum 6). Iraani religioonis ei olnud Mithra maailma looja (kuigi tal olid teatud kosmilised funktsioonid), küll oli ta seda aga partia- ja sogdikeelses maniluses ning Rooma keisririigi aegses Mithra kultuses. Viimases püstitati talle ka koobast imiteerivaid kultusruume. Porphyriose teade on mõistetav antiikmaailmas levinud traditsiooni taustal, mille järgi erinevad "salaõpetused" ja "salakultused" pärinesid idamaadest. Müütilisel targal Zoroastril ja iraani religiooni preestritel ehk "maagidel” oli selles traditsioonis oluline koht (De Jong 1997; Lahe 2014: 108). ${ }^{34}$ 


\section{II.2.6. Mithra Kušaani riigi müntidel ja raidkirjades}

Mithrat on kujutatud paljudel Kušaani riigi müntidel. Varaseimad kujutised pärinevad Soter Megase (u 80-100 pKr) müntidelt. Müntide esiküljel on kujutatud kuninga pead diadeemiga, mida ümbritsevad kiired. Kuningat on seega kujutatud Mithrana. Grenet' arvates on kuninga kujutis kopeeritud ilmselt ühelt hellenistlikult noolt hoidva Apollo raidkujult. Pärast varju jäämist Śiva kultust edendanud Vima Kadphisese valitsemise ajal ilmub Mithra uuesti nähtavale Kaniška I valitsusajast pärinevatel müntidel. Neil tähistatakse teda kreeka keeles esmakordselt Heliosena, baktria keeles aga Mihrina. Sarnasel kujul esineb ta ka Huviška müntidel (u 153-191). Tema pead ümbritseb alati kiirtega nimbus. Ta kannab iraanipäraseid rõivaid (tuunika, keep, saapad) ja sõdalase atribuute (mõõk, sageli ka oda). Kõige sagedamini vehib Mithra kõvera mõõgaga või mõõgaga, mida kaunistavad paelad. Grenet' arvates võib mõlemaid sümboleid tõlgendada kuningliku investituuri ehk veelgi spetsiifilisemalt, kuningliku khvarənahi sümbolitena (Grenet: http://www.iranicaonline. org/articles/mithra-2-iconography-in-iran-and-central-asia).

Mithra rolli ja funktsioonide üle Kušaani impeeriumi usundis on palju diskuteeritud. Ühest küljest on ta tänaseni leitud müntidel kõige sagedamini kujutatud meesjumalus, mis viitab tema populaarsusele Kušaani riigis, mille kuuluvus iraani kultuuriruumi on väljaspool kahtlust. Teiselt poolt on aga tema populaarsus olnud regionaalselt piiratud. Nimelt on leitud Mithra kujutistega münte kõige enam Baktria alalt ja sellega vahetult piirinevatelt territooriumidelt Kesk-Aasias, ent Kušaani riiki kuulunud aladelt Indias on leitud tema kujutisi väga vähe. Viimast seika saab seletada tõsiasjaga, et see ala jäi iraani kultuurituumist väljaspoole.

Kõige silmatorkavam joon Kušaani Mithra juures näib olevat tema solaarne iseloom. See kajastab ilmselt Partia ajajärgul iraani usundis toimunud muutust Mithra kujutamisel (vt 2.5). Kušaani müntidel kujutatud kiirtepärjaga Mithra kuulub olulise lülina iraani ikonograafilisse traditsiooni, mis saab alguse Partia ajajärgul ja ulatub sealt Sassaniidide ajastusse (vt 2.7; 2.8; 2.9). Kuna Mithra pead ümbritsev kiirtepärg ilmub ikonograafilise sümbolina esmakordselt nähtavale hellenistlikus Väike-Aasias, võib oletada selle motiivi laenamist iraani traditsiooni kreeka kunstist, kus see oli päikesejumal Heliose ikonograafiline tunnus juba hellenismiajastul.

H. Humbach on seisukohal, et kuigi kušaani müntidel leiduva Mıюo nimi on etümoloogiliselt identne Avesta Mithraga, on nende kahe funktsioonid mõlemas religioosses süsteemis väga erinevad. Kušaani panteonis on olemas selge korrelatsioon Miiro (Päikese) ja Māhi (Kuu) vahel. See ei ole kooskõlas zoroastristlike arusaamadega, nagu neid esitatakse Avestas, kus valitseb korrelatsioon 
Hvari (või Huuarexšaeta, Päikese) ja Māhi (Kuu) vahel. Kušaani panteonis mängib päikesejumal Ašaeixšo iseseisvat rolli, sellal kui Avestas mängib iseseisvat rolli Mithra (Humbach 1975: 137). See võib kinnitada hüpoteesi, mille kohaselt müntidel kajastuv iraani usund ei olnud zoroastrism (ibid.).

Erinevalt hellenistliku Väike-Aasia ja Iraani Sassaniidide reljeefidest ei leidu Kušaani müntidel ka midagi, mis vihjaks Mithrale kui lepingujumalale. Hellenistlikust Väike-Aasiast pärinevatel ja Sassaniidide reljeefidel on seevastu seda aspekti selgelt rõhutatud: kuningat ja Mithrat on kujutatud kätlemas (nagu seda võib näha Väike-Aasias) või on Mithrat kujutatud viibivana kuningliku investituuri juures (nagu on ühel 4. sajandist pärineval Sassaniidide kaljureljeefil). Kuid Mithra roll kuninglikus investituuris ei olnud tundmatu ka Kušaani riigis. Nii on juba mainitud keiser Kaniška reliikvialaekal kujutatud kuninga ametisseseadmist. Ametisseseadjateks on siin kuujumal Mao ja Mithra (Widengren 1965: 336). Mõnedel kušaani müntidel on seevastu kuninga ametisseseadjaks troonil istuv jumalus, keda ei ole suudetud identifitseerida. Mõned uurijad on pidanud teda Ahura Mazdāks (ibid.), ent siiski puudub selliseks samastamiseks alus. Oluline on aga asjaolu, et Mithra seos investituuri ja seega õiguslike suhetega oli tuntud ka Kušaani riigis.

Lisaks solaarsele iseloomule ja seosele õiguslike suhetega on Kušaani Mithra puhul oluline veel tema militaarne aspekt, millele vihjab jumala vööl rippuv mõõk. Tõsi - viimast kannab Kušaani müntidel vööl ka kuujumal Mao ning lisaks sellele on Kušaani panteonis veel mitu teistki sõjajumalat, ent see on mõistetav, kui mõtleme sellele, et Kušaani impeerium tekkis ja kasvas sõjaliste vallutuste tulemusena. Nagu eespool öeldud, oli Mithra puhul iraani usundis tema militaarne aspekt oluline juba Avestas ning sellele järgnenud pahlavikeelses kirjanduses tugevnes see veelgi. Nagu näitavad Hawartest (Süüria) leitud vangistatud deemoneid kujutavad maalingud, ei puudunud see aspekt Mithral ka Rooma keisririigis levinud Mithrase kultuses (Gawlikowski 1999: 197-204).

\section{II.2.7. Mithra Kušaani-Sassaniidi müntidel}

Pärast pikemat varjusolekut ilmneb Kušaani-Sassaniidi dünastia poolt väljalastud müntidel uus Mithra kujutamise viis - habemega Zeusi/Jupiteri tüüpi Mithra. Ühel Ardaširi kuldmündil, mis on selle seeria esimene, on kujutatud troonil istuvat kreeka tüüpi jumalat, kes kannab lintidega pärga. Jumal on tuvastatav tänu baktriakeelsele legendile Bago Miuro. Hilisemal väljalaskel on kujutatud sama jumalat, mõnikord istumas troonil ja hoidmas käes oda, ilmumas tulealtarist. Müntidel on legend burz'awand yazad ('jumal, kes valdab kõrgusi' keskpärsia või bakrtia transkriptsioonis). Seda võib tõlgendada tahtliku katsena ületada lõhet indoiraani jumalaga, kes esineb 3. sajandi Kušaani 
müntidel - jumal Wēšiga (Oēšo), kelle nimi ja kontseptsioon pärinevad Avestast (Vayuš [uparō.kairȳo-] 'Vayu, kes toimib kõrgustes'), kuid keda tema välimuse ja atribuutide põhjal on kuni tänaseni samastatud Śivaga. Selle asemel on uus sünkretistlik jumal säilitanud mõningaid muistseid Mithra iseloomujooni, nagu kiired või leegid ümber pea või isegi tiaara, mille kohal on poolkuu (detail, mis on palju silmapaistvamalt äratunutav eksemplaridel, mida kasutati Marvis Heratis). Samal ajal reedavad paljas rind, tema jalgade asend ja trooni kuju kreeka raidkujude mõju, mis olid Baktria templites tol ajal ajal ikka veel nähtavad (Grenet: http://www.iranicaonline.org/articles/mithra-2-iconographyin-iran-and-central-asia).

\section{II.2.8. Mithra kujutis Ohrmizd I müntidel}

Kuigi Mithra tähtsuses Sassaniidide ajajärgu Iraanis ei ole põhjust kahelda, leidub tema kujutis vaid ühe valitseja, Ohrmizd I müntidel. Jumalat kujutatakse neil ümbritsetuna kiirtepärjast, ulatamas kuningas Ohrmizdile üle tulealtari sõrmust. Ei ole kahtlust, et siin on nagu Kaniška relikviaari ja Tāq-e Bostān'i kaljureljeefi puhulgi tegemist investituuristseeniga (Grenet: http:// www.iranicaonline.org/articles/mithra-2-iconography-in-iran-and-central-asia).

\section{II.2.9. Mithra Tāq-e Bostāni kaljureljeefil}

Tāq-e Bostāni kaljureljeefil on kujutatud Sassaniidist valitsejat, keda on identifitseeritud erinevalt (Ardaxšir II või Šāpūr III) koos kahe jumalaga. Temast paremal seisab Ahura Mazda, kes ulatab kuningale paeltega kaunistatud diadeemi. Kuningast vasakul seisab Mithra, kes hoiab käes pikki barsomivarsi ja seisab lootoslillel. Mithra pead ümbritseb kiirtepärg. Nii jumala pead ümbritsevad kiired kui ka lootoslill vihjavad Mithrale kui päikesejumalale (Freye 1978: 205-211). Abolala Soudavar on tõlgendanud lootoslille xvarənah sümbolina (Souvadar 2003: 53-54). Xvarənah (vanapärsia farnah, uuspärs farr) tähenduses 'ausära, aupaiste, oreool' oli pühitsetud õigeusulise Iraani valitseja tunnus, mille kaotus oli võrdne langusega (Puhvel 1997: 112; vt ka Stausberg 2002: 211 ja Yarshater 1983: 345-346). Kuid ka khvarənahil on seos päikesega - mõiste on nimelt tuletatud sõnast 'päike' (hvar-, veda svar-, ladina sol) (Puhvel 1997: 112). On tähelepanuväärne, et Auramazdā ja Mithra esinevad siin koos, nagu nad esinesid Artaxerxes III raidkirjas $\mathrm{A}^{3} \mathrm{~Pa} 24-26$. Märkimisväärne on seegi, et nii nagu Kaniška reliikvialaekal, osaleb Mithra siingi kuninglikus investituuris. M. Stausberg oletab, et Mithra kui vandetõotuste jumal esineb siin 
vihjena vandele, mille Araxšir II olevat andnud pärast seda, kui ta Šāpūr II järglasena troonile astus. Ta olevat tõotanud, et annab oma võimu üle Šāpūr II pojale $^{35}$ pärast tolle täisealiseks saamist, mida ta ka tegi (Stausberg 2002: 214).

\section{II.2.10. Mithra kujutis Briti Muuseumis asuval Sassaniidide ajastu pitsatil}

Nimetatud pitsati publitseeris esmakordselt Pierfrancesco Callieri 1990. aastal (Callieri 1990: 79-98). Pitsatil on kujutatud Mithrat, keda ümbritseb nimbus ning kes kasvab välja otse Harā mäetipust, mida on kujutatud kerajate kaljude kolmnurgana. See kujutis meenutab väga mõningaid Mithra petrogenuse kujutisi Rooma keisririigi-aegsest Mithrase kultusest (Grenet: http://www. iranicaonline.org/articles/mithra-2-iconography-in-iran-and-central-asia). ${ }^{36}$

\section{II.2.11. Mithra Bāmīani seisvat Buddhat kujutava skulptuuri niši laemaalingul}

Kuigi nimetatud maaling paiknes ühe seisvat Buddhat kujutava skulptuuri niši laes, ei sisalda see äratuntavaid budistlikke elemente, kuid tervikuna näib see illustreerivat Mithra igapäevast epifaaniat nii, nagu seda on kirjeldatud Mihr Yaštis. Kompositstiooni raami moodustavad punakates toonides maalitud Harā mäestiku tipud. Nooruke jumal on seismas kaarikus, mida veavad neli valget härga ja juhib tiivuline figuur, kes on kõige tõenäolisemalt Aši. Mõlemal vankri küljel seisavad kaks tiivulist figuuri - vasakpoolne figuur on selgelt inspireeritud Athenast, kes hoiab gorgoneionit (Medusa pead), parempoolne figuur kujutab ühte vibukütti. Neid võib tõlgendada päikese- ja kuuvalgusena (kuigi Athena on samuti tuntud Mithra kaaslasena). Vātat, Tuult, keda mainitakse samuti Mihr Yaštis, sümboliseerib kaks figuuri maalingu ülemises osas. Kahte Mithraga samal kõrgusel lendavat preesterlike atribuutidega (padām, st kate nina ja suu jaoks, tõrvik, jookohvri jaoks mõeldud lusikas vööl) pool-linnu, pool-inimese figuuri on palju raskem tõlgendada; nende kuuluvust sogdi zoroastristlikku ikonograafiasse on tõendatud hiljutiste avastustega (ossuaariumid Samarkandist, väljaspool kodumaad elanud sogdide hauamonumendid Põhja-Hiinast) ja neid on tõlgendatud jumal Srōsi kukekujuliste avaldumisvormidena (Grenet: http://www.iranicaonline.org/ articles/mithra-2-iconography-in-iran-and-central-asia). 


\section{II.2.12. Kokkuvõte}

Mithra kohta iraani hõimude mütoloogias ja usundis tuleb tõdeda, et juba Avestas, mis on Ahhemeniidide raidkirjade kõrval vanim seda jumalust kajastav allikas, on tal olemas põhifunktsioonid, mida me kohtame hilisemates allikates: ta on (iraani hõimude) kaitsejumal, lepingutest kinnipidamise valvur ja lepingurikkujate karistaja, kurja vastu võitleja ning (kõige laiemas mõttes) viljakuse andja. Hõimude kaitsejumalana on tal ka selgelt äratuntavad sõjajumala jooned - ta annab iraani hõimudele võidu nende vaenlaste üle. Ta on ka seotud päikesega, kuid ei ole viimasega identne. Hiljem hakatakse teda päikesega samastama ning kujutama solaarsete atribuutidega. Hilisemates allikates maalitakse Avestas leiduvad ideed üksikasjalikumalt välja (näiteks kirjeldatakse detailselt tema võitlust deemonitega) ning uue funktsioonina lisandub talle kohtumõistja funktsioon surnutekohtus. Kuigi tekstides mainitakse Mithrat koos paljude teiste jumalatega (Ahura Mazdā, Vohu Manah, Sraoša, Rašnu), on ta suhteliselt iseseisev jumalus, kellel puudub kindel paariline. Mithra näol on olnud vaieldamatult tegemist ühe iraani usundi populaarseima jumalusega ja seda on ta olnud suurema osa iraani usundi ajaloost.

\section{II.3. India Mitra ja iraani Mithra sarnasused ja erinevused}

Nagu juba sissejuhatuses nimetatud, pakub Avesta Rgveda jumalustele huvitavaid paralleele. Ahura Mazdā ja Asura Varuṇa kaaslane on Avestas ja Rgvedas sama - Avestas MiOra, Rgvedas Mitra (Puhvel 1997: 107; Macdonell 1897: 7). On üsna suur hulk täpseid kokkulangevusi sõnavaras, mis näitavad Avesta MiӨra ja veedade Mitra seost. Viimastest nimetab Hans-Peter Schmidt järgmisi:

MiOra/Mitra on kummardamist vääriv (yesnya, Yt 10.5; yajñiyá, RV 9.77.5); MiOrat/Mitrat austatakse kummardustega (nəmah, Yt 10.6; namasyà, RV 3.59.4); Mithra on maa laius (zəm.fraqå, Yt 10.95) ja ta kõnnib ümber maa äärte ning valvab kõigi asjade üle taeva ja maa vahel (Yt 10.36; 10.76; 10.107). Mitral on avarus (sapráthas, RV 3.59.7) ning ta ulatub ümber taeva ja maa. Ta on ärgas (jagauruuah, Yt 10.7; jāgrvás, RV 1.136.3), ilma uneta (axvafna, Yt 10.7), nagu seda on ka Ādityad (ásvapnaj, RV 2.27.9). Ta hävitab (frazinte, 10.38) lepingurikkujate elamud, sellal kui see, kes pingutab ennast oma tänukohustustes Mitra vastu, ei hävi (ná jiyate, RV 3.59.2, vrdl 10.152.1). MiӨrat kutsutakse üles halastama (Yt marždika, 10.5) ja tema kohta öeldakse, et ta on väga halastav ( huuāmarždika, Yt 10.140); Mitrat ja Varuṇat kutsutakse andestavateks (mrdáyant, RV 1.136.1), kuid palju sagedamini palutakse halastust üksnes Varuṇalt. MiOra võib olla vihane (zarəmna, Yt 10.47) ja seda võib olla 
ka Mitra (jujurāṇá, RV 10.12.5). MiӨra on liidu lõhkujate karistaja (acaētar) (Yt 10.26), Mitra, Varuṇa ja Aryaman on vale karistajad (cetár) (RV 7.60.5). MiӨra kaitseb maad, mis hoolitseb kindlalt (enda ja lepingu) hea seisukorra eest (yātayeiti, Yt 10.78); Mitra innustab rahvast pidama kinni lepingust

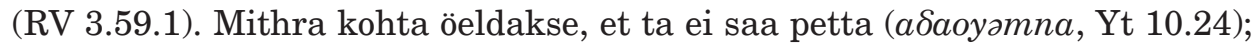
ka Ādityasid kutsutakse sageli nii (ádabdha, RV 1.24.13, 2.27.3 ja 9, 7.60.5). MiӨral on nuhid ja ta on ise nuhk (spas, Yt 10.45, 46); Varunal on nuhid (spaś, RV 7.87.3; 9.73.4) (Schmidt: http://www.iranicaonline.org/articles/mithra-i).

Ent kokkulangevusi ja sarnaseid jooni võib välja tuua veelgi. Kui Rgveda Varuṇal on tuhat silma, on Avesta MiӨral neid kümme tuhat (võrdle Yt 10.7; 10.41; 10.82; 10,91 - RV VII,34,10). MiOra/Mitra kaitseb kõiki olendeid, on eluandja ning abistaja ahistuses, kitsikuses (võrdle Yt 10.4; 10.5; 10.16; 10.30; 10.54; 10.65; 10.75 - RV III,59,2 ja 8; IV,55,1; V,65,5; VII,82,5). Sarnaselt Rgveda Mitrale ja Varunale on Avesta MiOra taeva ja maa toetaja (Yt 10.95), võlujõu valdaja (Yt 10.25), raevukas jumal ning jumal, kes laseb vihmal sadada (Yt 10.61). Nagu Mitral, nii on ka MiOral side päikese (Yt 10.7; 10.12; 10.44; $10.103 ; 10.142 ; 10.143 ;$ Vendīdād 19.28) ja tulega (Yt 10.3).

Silmatorkavaks erinevuseks veedade Mitra ja Avesta MiӨra vahel on see, et esimesel puuduvad militaarsed jooned peaaegu täielikult. Veedades on need üle võtnud jumal-sõdalane Indra. Indra on see, kellel on võim liitude üle (1.170.5). Ta maksab kätte neile, kes purustavad liite, kes petavad Mitra ja Varuna institutsioone, liitlasi; kes on teritanud oma relva liitlase vastu amítra ('ilma lepinguta'; 10.89.8-9). Indra on jumal, kes võtab väga sageli ette aktsioone nende vastu, kes on amítra, st, kes on keeldunud tegemast rahu või ei ole tunnustanud jumal Mitrat. Indra puhastab tõega (rtá) kahte maailma, põletades petjad (drúh), kes ei tunnusta Indrat (aníndra); ta püüab kinni, tapab ja purustab amítra (1.133.1). On palju juhtumeid, kui Mitra ja Varuna kasutavad relvi. Nad kasutavad püüniseid (7.63.3) ja nooli (nt 8.100.3, 5), mis on maagilised vahendid oletatavasti tõe ja lepingu rikkujate karistamiseks. Sõjakaid jooni võib näha aga tema ronimises (sõja)vankrisse (5.63.1) ja selles, et tema (sõja) vanker teeb kahju inimestele, kes toimivad valesti (AV 4.29.7) (Schmidt: http:// www.iranicaonline.org/articles/mithra-i).

MiOra/Mitra olulisusele viitab asjaolu, et ta esineb paaris peamise jumalusega: Avestas leidub MiӨra ja Ahura ning Rgvedas Mitra ja Varuṇa paar. Ainsaks probleemiks on seejuures vaid asjaolu, et Avestas on küll viiteid MiOra ja Ahura ühistegevusele (Yt 10.113; X,145; Yasna I,11; II,11; III,13), ent samas on see jumalik paar Ahura Mazdāst eristatud (vt Gonda 1974: 164-165). Näib, et Zarathustra reformi käigus, mil Ahura Mazdā tõsteti peajumalaks, lahutati ta oma vanast paarilisest MiӨrast. Tekstides, mis on reformeeritud põhimõtetega ühtlustamata, säilis vana MiӨra ja Ahura paar. 
Mitra/MiӨra sarnased jooned viitavad jumala pärinemisele indo-aaria ühisajastust. Ometi kulges areng Indias ja Iraanis erinevalt. Kui Indias lõppes Mitra areng jumalusena Śatapatha brāhmanaga, mille kirjutamisaeg paigutatakse 8.-6. sajandisse eKr (vt 1.3), hakkas Mithra Iraanis uuesti esile tõusma alles Ahhemeniidide ajajärgul (6.-4. saj eKr). Kuigi ta säilitas eelpool kirjeldatud ühisjooned India Mitraga, ilmuvad talle juba Avestas jooned, mida Mitral Indias ei kohta. Nii astub Mithra Iraani tekstides üles kui kohtumõistja surnute üle ning võitleja deemonite vastu. Indias ei ole ta kumbki ja ka deemonitega võitlemine on eeskätt Indra ülesanne. Kuigi seos Päikesega on mõlemal jumalal juba nii veedades kui ka Avestas, toimub iraani kultuuriruumis veidi enne meie ajaarvamist Mithra ja Päikese täielik samastamine ning alates sellest hakkab Mithra solaarne aspekt domineerima paljude tema teiste aspektide üle. Suurimaks erinevuseks India Mitra ja Iraani MiӨra/Mithra vahel on aga ilmselt see, et kui Indias esineb Mitra peaaegu alati paaris Varunaga, saab temast Iraanis iseseisev jumalus, kelle kultusest võib leida jälgi peaaegu tervest iraani kultuuriruumist Väike-Aasiast ja Armeeniast kuni Kesk-Aasiani. Kuigi Rooma keisririigis levinud jumal Mithrase kultust ei saa käsitleda Iraani Mithra kultuse jätkuna ega tuletada viimasest, on ometi fakt, et ka Rooma riigis säilitab Mithra kuju mitmeid jooni, mis iseloomustasid teda muistses Indias ja Iraanis ning võib-olla isegi juba indoiraani ühisperioodil (vt Merkelbach 1994: 3-39; Lahe 2014: 78-110). Seepärast kuulub Rooma Mithrase kultus vähemalt indoiraani Mitra/Mithra retseptsioonilukku.

\section{Kommentaarid}

1 Indoeuroopa hõimud asusid hõivama uusi territooriume Aasias ja Euroopas 2. aastatuhandel eKr (vt Puhvel 1996: 42-50; Ghirshman 1978: 73-74; Diakonoff 2007: 41-57). Ajavahemikus u 1750-1200 eKr tungisid Indiasse aarialaste (skr ārya) nime all tuntud hõimud, kes alistasid siinsed põlisasukad ning panid aluse indoeuroopa tsivilisatsioonile (selle perioodi kohta India ajaloos vt Danielou 2011: 40-63), mida on nimetatud ka "hindu tsivilisatsiooniks" ja mis on järjepidevalt säilinud kuni tänaseni. 2. aastuhande esimesel poolel või 1 . alguses eKr jõudis teine suurem indoeurooplaste sisserännulaine Iraani kiltmaale. Ka Iraani territooriumile asunud hõimud tähistasid ennast aarialastena, millest on tuletatud maa nimi Iraan (muinaspärsia Büm- $\bar{\imath}$ aryānam - aarialaste maa). Mõlemat hõimuharu nimetatakse indoiraani hõimudeks ning nende kõneldud keeli vaadeldakse proto-indoeuroopa keelte ühe haru erinevate murretena (Diakonoff 1985: 41). Erinevalt Indiast on araablaste vallutuste tõttu suurem osa muistsest iraani tsivilisatsioonist tänaseks aga hääbunud, olles säilinud vaid reliktidena mägipiirkondades (näit kurdidega asustatud aladel, samuti Osseetias) ning muutunud kujul ka valdavalt väljaspool Iraani (kõige arvukamalt Indias, kuid ka Ameerika Ühendriikides, Kanadas, Austraalias, Suurbritannias jm) asuvate parside hulgas, kes on muistse iraani usundi zoroastrismi järgijate otsesed järeltulijad (zoroastrismi kohta kõige varasemast ajast kuni tänapäevani vt Stausberg et al. 2015). 
Vähesel määral leidub islamieelse iraani usundi järgijaid ka Iraanis, zoroastrismi kohta tänapäeva Iraanis vt Stausberg 2011: 9-11. Islami revolutsioonile eelnenud aja kohta vt ka Kestenberg Amighi 2016: http://www.iranicaonline.org/articles/ Zoroastrians-in-Iran-04.

2 Tähtsamate muinasiraani jumalate ja nende india vastetena olgu nimetatud järgmised: deemonlik Nanhaitya (skr Nāsatya, Aśvinite duaalne lisanimi), tuulejumalad Vayu (skr Vāyu) ja Vāta (skr Vāta), jumalik jook haoma (skr soma), peajumala saadik Apam Napāt (skr Apāṃ Napāt), haomasuruja Vīvạhvat (skr Vivasvat), Vīvạhvati poeg ja kuldse ajastu müütiline valitseja Iima (skr Yama), deemon Gandardwa (skr

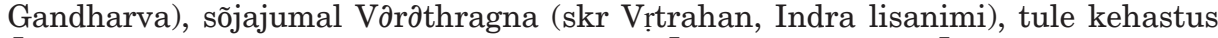
$\bar{A} \operatorname{tar}$ (skr Agni) ning haomasurujad Thrita ja Āthwya (skr Trita Āptya).

3 Seda küsimust on käsitlenud nt Stig Wikander (1938), Friedrich Walter Lenz (1970) ja Georges Dumézil (vt Dumézil 1988 ja ka Dumézil 2001).

4 Etümoloogia kohta vt veel Bailey 1975: 15-16; Thieme 1975: 21-33; Schmidt 1978: 345-394; Puhvel 1978: 47-57; Bonfante 1978: 47-57; Mayerhofer 1978: 317-325.

5 See on Hetiidi kuninga Šuppiluliuma I ja Mitanni vürsti Sattiwaza/Mattiwaza/ Kurtiwaza vahel sõlmitud leping, mis on dateeritud u aastasse $1380 \mathrm{eKr}$. Lepingus mainitakse Mitrat (mi-it-ra-aš-ši-il) teadaolevalt esmakordselt. Vt Thieme 1960: 301-317; Bailey 1975: 1; Schmeja 1975: 5.

6 Vt täpsemalt Kalda 2015: 109-121.

7 Sõna avesta tähenduse ja etümoloogia kohta vt Kellens: http://www.iranicaonline.org/ articles/avesta-holy-book; Stausberg 2002: 69.

8 Ühe hüpoteesi järgi on säilinud vaid veerand Sassaniidide aja Avesta tekstist (Udam 2001: 68).

9 Teose kohta lähemalt vt Stausberg 2002: 295 jj.

${ }^{10}$ Nende kontaktide kohta vt Burkert 2009: 107-133.

${ }^{11}$ Kušaani riigi kohta vt Bivar 1983: 198-209; Zeimal 1983: 231-262; Sagar 2016: 16441683, 1841-1853; Harmatta 1994a; Litvinsky 1996.

12 Usundite kohta Kušaani riigis vt Colpe 1983: 847-851; Harmatta et al. 1994: 313-329; Lahe 2016: 96-105.

${ }^{13}$ Väike-Aasia langes Pärsia valitsuse alla juba Ahhemeniidide perioodil (selle kohta vt Schwertheim 2005: 43-54; Marek 2010: 204-227. Iraani kultuurimõjusid Väike-Aasias on ülevaatlikult käsitlenud Leo Raditsa (Raditsa 1983: 100-114), põhjalikumalt aga Walter Burkert (vt Burkert 2016: 152-187).

${ }^{14}$ Olgu siinkohal mainitud, et ka Rooma raidkirjades esineb jumala nimest Mithras erinevaid vorme (vt Lahe 2014: 78-110). Müntide kui Kušaani riigi usundiloo allikate kohta vt Humbach 1975: 135-141; MacDowall 1975: 142-150; MacDowall 1978: 305-316.

${ }^{15}$ Kaniška valitsusaega on dateeritud erinevalt (selle kohta vt Sagar 2016: 1659-1664), kuid tõenäoliselt tuleb see paigutada umbes ajavahemikku u 130-170 pKr. Kõigi Kušaani kuningate valitsusaegade dateeringud on äärmiselt kõikuvad (vt selle kohta: ibid.).

${ }^{16}$ Kujutiste kohta vt Lahe 2016: 105-108; Grenet: http://www.iranicaonline.org/articles/ mithra-2-iconography-in-iran-and-central-asia. Lootost on tõlgendatud ka xvarənah sümbolina (vt Soudavar 2003: 53-54). 
${ }^{17}$ Näiteks kohtab Gāthā hümnides küll sõna mitmusevormi, ent seal tähistab see lihtsalt 'liite' (sks Bündnisse), kusjuures ei ole selge, kas tegemist on meessoost või kesksoost sõnaga (Lommel 1927: 62).

${ }^{18}$ Algselt tähendas jazata muinaspärsia usundis lihtsalt jumalat, olles mõnikord sõna bhaga sünonüümiks (viimane on suguluses veedades esineva Bhagaga (üks jumalatest, kelle nime algne tähendus on 'jagu') ning vanaslaavi sõnaga bogu ('jumal')). Hiljem hakkab jazata (eriti mitmuses: yazatas) tähistama zoroastrismis jumalikke olendeid, kes kaitsevad inimesi ja võitlevad kurjade vaimude vastu. Neid on võrreldud inglitega juudi-kristlikus ja islami traditsioonis.

${ }^{19}$ Aša kontseptsiooni kohta vt Nyberg: 1966: 129-133; Stausberg 2011: 38-40.

${ }^{20}$ L. Gray väidab, et Mithra nimi on tuletatud tüvest * $m \bar{e}$ (mõõtma), eeldades, et Mitra oli päikese kui päeva "mõõtja” nimetus (Gray 1929: 96 jj).

${ }^{21}$ Yašt 10.136 kutsutakse päikest Mithra vaša aeuua.caxra ('Mithra üherattaline kaarik'). See on väljend, millel on indoiraani päritolu, nagu me näeme Indias Rgveda I.164.2, kus ka päikesejumala Sūrya kaarikut nimetatakse ratha ekacakra ('üherattaline kaarik') (Humbach 1975: 137).

${ }^{22}$ Seda aspekti on põhjalikult käsitlenud A. A. Jafarey (1975: 54-61).

${ }^{23}$ Mithra kui hingede kohtumõistja kohta vt ka Shaked 1980: 1-30.

${ }^{24}$ Nii juba Dareios I raidkirjades. Vt Stausberg 2002: 166-167.

${ }^{25} \mathrm{~A}^{2} \mathrm{Sd}$; A²Ha. A²Hb; vt Schmidt 2009: 187, 194-197.

${ }^{26}$ Aga ta lisab juurde: "Mulle näib nii."

${ }^{27}$ Siin on tegemist nn interpretaio graecaga, mis kirjeldab iraani usundit kreeka jumalanimede abil. Sama teeb Herodotos mujal oma teoses ka egiptuse jt religioonidega.

${ }^{28}$ Vt nende kohta Puhvel 1996: 105.

${ }^{29}$ Ailianos (sünd u $200 \mathrm{eKr}$ ), kreeka keeles kirjutanud Rooma kirjanik, kuulus nn kirevate kirjanike hulka, kes kirjutasid õpetlikke ja moraliseerivaid lugusid loodusest ja ajaloost.

${ }^{30}$ Pseudo-Kallisthenes, 3. saj pKr elanud autor, kes koostas Aleksander Suure elu käsitleva teose, mis tugineb Aleksandri kaasaegse Makedoonia ajalookirjutaja Kallisthenese (u 370 - u $327 \mathrm{eKr}$ ) teosele "Aleksandri teod".

${ }^{31}$ Herodotos (I 131) ja Strabon (XV,13,3) teatavad, et pärslased austasid kultuslikult päikest. Eraldi mainitakse seda kuningate puhul: Xerxes I palvetas loojuva päikese poole (VI,54) ja Dareios III telgis oli Curtius Rufuse teatel päikese kujutis (III,3,8). Tule kõrval pöördus Dareios vägede ülevaatuse ajal ka päikese poole (IV,13,2). Xenophon teatab (Anabasis IV,5,35), et Kyros laskis päikesele ohverdada hobuse. Ka Philostratos jutustab “Tyana Apolloniuse elus" (I,18), kuidas Partia kuningas ohverdas päikesele valge hobuse. Juba Ahhemeniidide ajajärgul peeti Mithra auks mithrakana-püha. Straboni andmetel ohverdati Armeenias partia ajajärgul sel pühal 20000 hobust (Geographica, XI, 14, 9). Justinus Märter teatab, et pärslased uskusid, et päike on jumal ja et ta hobused on pühad (Apol I,10,3-5).

32 Nende kohta vt Dörner 1978: 123-133; Wagner 2012: 43-60; Jacobs 2012: 77-87; Lahe 2015: 186-196.

33 Selle kohta vt Lahe 2014: 107-108.

${ }^{34}$ Probleemi kohta vt ka Dihle 1994: 105-121; Burkert 2004: 107-133; De Jong 1997. Kreeklaste ja roomlaste oriendi-kontseptsiooni ja oriendi-lummuse kohta laiemalt 
vt Lahe 2012: 151-195; Belayche 2013: 74-75; Bonnet 2009; Auffarth 2006; Auffarth 2007a; Auffarth 2007b.

35 Valitses Šāpūr III nime all.

${ }^{36}$ Rooma Mithrase kaljust sündimise kohta vt näit Vermaseren 1965: 59-63; Clauss 2012: 65-72.

\section{Allikad}

\section{India allikad}

Jelizarenkova, Tatjana (tlk) 1972. Rigveda: Izbrannye gimny. Moskva: Akademia Nauk SSSR; Nauka.

Kalda, Martti (tlk) 2015. Śatapatha brāhmaṇa XI,5,1,1-17: Purūravas ja Urvaśī. Kulmar, Tarmo (peatoim). Idakiri. Eesti Akadeemilise Orientaalseltsi aastaraamat. Tartu: Eesti Akadeemiline Orientaalselts, lk 109-121.

Muir, John (kogunud ja tlk) 1870. Original Sanskrit Texts on the Origin and Progress of the Religion and Institutions of India. Vol V. London: Trübner \& Co.

\section{Iraani usundit kajastavad allikad}

Curtius Rufus. Historiarum Alexandri Magni (http://www.thelatinlibrary.com/curtius. html -15. november 2016).

Gershevitsch, Ilya (tlk) 1967. The Avestan Hymn to Mithra with an introduction, translation and commentary. Cambridge: Cambridge University Press.

Humbach, Helmut 1960. Die Kanishka-Inschrift von Surkh Kotal. Ein Zeugnis des jüngeren Mithraismus aus Iran. Wiesbaden: Harrassowitz Verlag.

Humbach, Helmut (tlk) 1991. The Gathas of Zarathushtra and the Other Old Avestan Texts. Part I: Introduction - Text and Translation. Heidelberg: Winter.

Justinus. 1. Apologia (http://www.newadvent.org/fathers/0126.htm - 15. november 2016).

Kyroupaideia = Cyropaedia: The Education of Cyrus. Translated by Henry Graham Dakyns. London: Macmillan 1914.

Lecoq, Pierre (kogunud ja tlk) 1997. Les inscriptions de la Perse achemenide. Paris: Gallimard.

Lommel, Herman (tlk) 1927. Die Yäšt’s des Awesta. Göttingen: Vandenhoeck \& Ruprecht.

Macaulay, G. C. (tlk). The History of Herodotus. Paralleel English/ Greek (http://www. sacred-texts.com/cla/hh/index.htm - 15. november 2016).

Oikonomikos (https://ebooks.adelaide.edu.au/x/xenophon/x5oe/ - 15. november 2016).

Philostratos. Ta es ton Tyanea Apollonion = Life of Apollonius (http://www.livius.org/ sources/content/philostratus-life-of-apollonius/? - 15. november 2016). 
Porphyrios. De antro nymphrorum (http://www.tertullian.org/fathers/porphyry_cave_ of_nymphs_02_translation.htm - 15. november 2016).

Schmidt, Rüdiger (kogunud ja tlk) 2009. Die Altpersischen Inschriften der Achaimenididen. Wiesbaden: Dr. Ludwig Reichert Verlag.

Strabon. Geographica (http://penelope.uchicago.edu/Thayer/E/Roman/Texts/Strabo/ home.html - 15. november 2016).

Tehmuras, Behramgore Anklesaria (tlk) 1956. A translation of the Iranian or Greater Bundahišn. Bombay (http://www.avesta.org/mp/grb.htm - 15. november 2016).

Wolff, Fritz (tlk) 1910. Avesta. Die heiligen Bücher der Parsen. Strassburg: K. J. Tübner.

Xenophon. Anabasis (https://books.google.ee/books?id=gyQUAAAAQAAJ\&hl=et\&sour ce=gbs_similarbooks -15 . november 2016).

\section{Kirjandus}

Alvar, Jaime 2008. Romanising oriental Gods: myth, salvation and ethics in the cults of Cybele, Isis and Mithras. Leiden \& Boston: Brill.

Auffarth, Christoph 2006. 'Licht vom Osten': Die antiken Mysterienkulte als Vorläufer, Gegenmodell oder katholisches Gift zum Christentum. Archiv für Religionsgeschichte 8 (1), lk 206-226.

Auffarth, Christoph 2007a. Zwischen Anpassung und Exotik. 'Mysterien' und 'Orientalische Kulte' in der Religion der Antike. Verkündigung und Forschung 2, lk 19-30 (doi: 10.14315/vf-2007-0204).

Auffarth, Christoph 2007b. Religio migrans: Die 'Orientalischen Religionen' im Kontext antiker Religion. Ein theoretisches Modell. Mediterranea 4, lk 333-363.

Bailey, Harold W. 1975. The second stratum of the Indo-Iranian gods. Hinnells, John R. (toim). Mithraic Studies. Proceedings of the First International Congress of Mithraic Studies, 1. Manchester: Manchester University Press, lk 1-20.

Bartholomae, Friedrich Christian Leonhard 1904. Altiranisches Wörterbuch, Strassburg: Trübner.

Belayche, Nicole 2013. Der "Orient" im römischen Sicht. Zwischen Geographie und kultureller Alterität. Hattler, Claus (toim). Imperium der Götter. Isis, Mithras, Christus. Kulte und Religion im römischen Reich. Karlsruhe: Badisches Landesmuseum. Stuttgart: Konrad Theiss Verlag, lk 74-75.

Bivar, Adrian David Hugh 1983 The History of Eastern Iran. Yarshater, Ehsan (toim). The Cambridge History of Iran 3 (1): The Seleucid, Parthian and Sasanian Periods. Cambridge: Cambridge University Press, $1 \mathrm{k}$ 181-231.

Bonfante, Giulio 1978. The Name of Mithra. Études Mithraiques. Acta Iranica 17, lk 47-57. 
Bonnet, Corinne 2009. Die ‘Orientalischen Religionen' im Laboratorium des Hellenismus: Franz Cumont. Trivium. Revue franco-allemande de sciences humaines et sociales Deutsch-französische Zeitschrift für Geistes- und Sozialwissenschaften (https://trivium. revues.org/3452 - 9. november 2016).

Boyce, Mary 1969. On Mithra's part in Zoroastrianism. Bulletin of the School of Oriental and African Studies, University of London 32 (1), lk 10-34.

Boyce, Mary 1975a. A History of Zoroastrianism. Vol. 1. The Early Period. Leiden: Brill. Boyce, Mary 1975b. Mithra, Lord of Fire. Monumentum H.S. Nyberg I. Acta Iranica 4. Leiden: Brill, lk 69-76.

Boyce, Mary 1979. Zoroastrians. Their Religious Beliefs and Practices. London \& Boston \& Henly: Routledge \& Kegan Paul.

Boyce, Mary 1992. Zoroastrianism, Its Antiquity and Constant Vigour. Costa Mesa (California): Mazda.

Brereton, Joel Peter 1981. The Rgvedic Ādityas. American Oriental Series 63. New Haven: American Oriental Society.

Burkert, Walter 2004. Babylon, Memphis, Persepolis: Eastern Contexts of Greek Culture. Cambridge \& London: Harvard University Press.

Burkert, Walter 2016. Kreeklased ja idamaad. Homerosest maagideni. Saksa keelest tõlkinud Jaan Lahe. Tallinn: Tallinna Ülikooli Kirjastus.

Callieri, Pierfrancesco 1990. On the Diffusion of the Mithra Images in Sasanian Iran. New evidence from a Seal in the British Museum. East and West 40, lk 79-98.

Clauss, Manfred 2012. Mithras. Kult und Mysterium. Darmstadt: Wissenschaftliche Buchgesellschaft.

Colpe, Carsten 1983. Development of religious thought. Yarshater, Ehsan (toim). The Cambridge History of Iran. Vol. 3 (2): The Seleucid, Parthian and Sasanian Periods. Cambridge: Cambridge University Press, lk 819-865.

Danielou, Alain 2011. India ajalugu. Inglise keelest tõlkinud ja kommenteerinud Martti Kalda. Tallinn: Valgus.

De Jong, Albert 1997. Traditions of the Magi. Zoroastrianism in Greek \& Latin Literature. Religions in the Graeco-Roman World 133. Leiden: Brill.

Diakonoff, Igor Mihhalovitš 2007. Media. Gershevitsch, Ilya (toim). The Cambridge History of Iran. Vol. 2 The Median and Achaemenian Periods. Cambridge: Cambridge University Press, lk 36-148.

Dihle, Albrecht 1994. Die Griechen und die Fremden. München: Beck.

Dörner, Friedrich Karl 1978. Mithras in Kommagene. Études Mithraiques. Acta Iranica 17. Teheran \& Liège: Bibliothèque Pahlavi, lk 123-133.

Duchesne-Guillemin, Jacques 1962. La Religion de l'Iran Ancien. Paris: Presses Universitaire de France. 
Dumézil, Georges 1945. Naissance d'archanges. Paris: Gallimard.

Dumézil, Georges 1988. Mitra-Varuna. An Essay on Two Indo-European Representations of Sovereignty. New York: Zone.

Dumézil, Georges 2001. Indoeurooplaste mü̈̈did ja jumalad. Tlk Marri Amon, Lembe Lokk. Tallinn: Varrak.

Freye, Richard 1978. Mithra in Iranian Archaology. Études Mithraiques. Acta Iranica 17. Teheran \& Liège: Bibliothèque Pahlavi, lk 205-211.

Frye, Richard Nelson 2015. Mithra Iraani ajaloos. Tlk Jaan Lahe. Akadeemia 11, lk 2010-2022.

Gawlikowski, Michał 1999. Hawarti: Preliminary Report. Polish Archeology in the Mediterranean 10, lk 197-204.

Gershevitsch, Ilya 1975. Die Sonne das Beste. Hinnells, John R. (toim). Mithraic studies. Proceedings of the First International Congress of Mithraic Studies. Volume I. Manchester: Manchester University Press, lk 68-89.

Ghirshman, Roman 1978. Iran. From the earliest Times to the islamic Conquest. Harmondsworth: Penquin Books.

Gnoli, Gherardo 1979. Sol persice Mitra. Bianchi, Ugo (toim). Mysteria Mithrae. Etudes préliminaires aux religions orientales dans l'empire romain 80. Leiden: Brill, lk 725-740.

Gonda, Jan 1974. The Dual Deities in the Religion of the Veda. Amsterdam: Verhandelingen der Koninklijke Nederlandse Akademie van Wetenschappen, Afd. Letterkunde, Nieuwe Reeks, Deel LXXXI, North-Holland Publishing Co.

Gordon, Richard 2000. Mithras. Der Neue Pauly Enzyklopädie der Antike 8. Stuttgart: Metzler, lk 287-291.

Gordon, Richard 2012. Mithras (Mithraskult). Reallexikon für Antike und Christentum XXIV. Stuttgart: Anton Hiersemann, lk 964-1009.

Gray, Louis H. 1929. The Foundations of the Iranian Religions. K. R. Cama Oriental Institute Publication 5. Bombay: Cama Oriental Institute.

Grenet, Frantz. Mithra ii. Iconography in Iran and Central Asia. Encyckopaedia Iranica (http://www.iranicaonline.org/articles/mithra-2-iconography-in-iran-and-central-asia 10. november 2016).

Harmatta, János (toim) 1994a. History of civilizations of Central Asia, Volume II. The development of sedentary and nomadic civilizations: 700 B.C. to A.D. 250. Paris: UNESCO Publishing (http://unesdoc.unesco.org/images/0010/001057/105703eo.pdf - 10. november 2016).

Harmatta, János 1994b. Languages and literature of the Kushan Empire. Harmatta, János (toim). History of civilizations of Central Asia, Volume II, The development of sedentary and nomadic civilizations: 700 B.C. to A.D. 250. Paris: UNESCO Publishing, lk 427-432 (http://unesdoc.unesco.org/images/0010/001057/105703eo.pdf - 10. november 2016). 
Harmatta, János \& Puri, B. N. \& Etemadi, G. F. (toim) 1994. History of civilizations of Central Asia. Volume II. The development of sedentary and nomadic civilizations: 700 B. C. to A. D. 250. Paris: Unesco Publishing (http://unesdoc.unesco.org/ images/0010/001057/105703eo.pdf - 10. november 2016).

Henning, Walter Bruno. The Baktrian inscription (https://www.azargoshnasp.net/ languages/Sogh/Thebactrianinscription.pdf - 10. november). [Esmatrükk: 1960. The Baktrian inscription. Bulletin of the School of Oriental and African Studies 23 (1), lk 47-55 (doi: 10.1017/S0041977X00148980).]

Herzfeld, Ernst 1947. Zoroaster and his World. Princeton: Princeton University Press. Hillebrandt, Alfred 1990 [1980]. Vedic Mythology. Delhi: Motilal Barnasidass Publishers. Humbach, Helmut 1975. Mithra in the Kusana periood. Hinnells, John R. (toim). Mithraic studies. Proceedings of the First International Congress of Mithraic Studies. Volume I. Manchester: Manchester University Press, lk 135-141.

Jafarey, Ali A. 1975. Mithra, Lord of Lands. Mithraic Studies. Proceedings of the First International Congress of Mithraic Studies. Volume I. Hinnells, John R. (toim). Manchester: Manchester University Press, lk 54-61.

Jacobs, Bruno 2012. Das Heiligtum auf dem Nemrud Dagi - Zur Baupolitik des Antiochos I. von Kommagene und seines Sohnes Mithradates II. Wagner, Jörg (koost). Gottkönige am Eufrat. Neue Ausgrabungen und Forschungen in Kommagene. Darmstadt \& Mainz: Verlag Philipp von Zabern, lk 77-87.

Kellens, Jean. Avesta i. Survey of the history and contents of the book. Encyckopaedia Iranica (http://www.iranicaonline.org/articles/avesta-holy-book - 10. november 2016).

Kerstenberg Amighi, Janet 2016. Zoroastrians of Iran IV: Between the Constitutional and the Islamic Revolutions. Encyclopaedia Iranica (http://www.iranicaonline.org/articles/ Zoroastrians-in-Iran-04 - 10. november 2016).

Lahe, Jaan 2014. Hat der römische Mithras-Kult etwas mit dem Iran zu tun? Überlegungen zu Beziehungen zwischen dem römischen Mithras-Kult und der iranischen religiösen Überlieferung. Usuteaduslik Ajakiri 2, lk 78-110 (http://usuteadus.ee/wordpress/wpcontent/uploads/2014_2\%20(67)/UA-2014-2-7.Lahe_.pdf - 10. november 2016).

Lahe, Jaan 2015. Mithra in Kleinasien und Mithra(s) im Römerreich: Sind die römische Mithras-Mysterien in Kleinasien entstanden? Espak, Peeter \& Läänemets, Märt \& Sazonov, Vladimir (toim). Sudia in Honorem Tarmo Kulmar. When Gods Spoke. Researches and Reflections on Religious Phenomena and Artefacts. Studia Orientalia Tartuensia. Series Nova VI. Tartu: University of Tartu Press, lk 186-196.

Lahe, Jaan 2016. Mithra kultus Kušaani riigis ja iraani usundis. Kulmar, Tarmo (peatoim). Idakiri. Eesti Akadeemilise Orientaalseltsi aastaraamat 2015. Tartu: Eesti Akadeemiline Orientaalselts, lk 96-105.

Lenz, Fiedrich Walter 1970. The 'Social Functions' of the Old Iranian Mithra. Boyce, Mary \& Gershevitch, Ilya. W.B. Henning Memorial Volume. Asia major Library. London: Lund Humphries Publishers Ltd, lk 245-255. 
Litvinsky, B. A. (toim) 1996. History of civilizations of Central Asia, Volume III. The crossroads of civilizations: A.D. 250 to 750. Paris: UNESCO Publishing (http://unesdoc. unesco.org/images/0010/001046/104612e.pdf - 10. november 2016).

Lommel, Herman 1930. Die Religion Zarathustras. Nach dem Awesta dargestellt. Tübingen: J. C. B. Mohr (Paul Siececk).

Lommel, Herman 1944-1949. Mithra und das Stieropfer. Paideuma 3, lk 207-218.

Lommel, Herman 1962. Die Sonne das Schlechteste? Strophe 10 der fünften Gāthā des Zarathuštra, Yasna 32. Oriens 15, lk 360-373 (doi: 10.2307/1579862).

Lommel, Herman 1964. Kopfdämonen im alten Indien. Symbolon. Jahrbuch für Symbolforschung 4. Basel \& Stuttgart: Benno Schwabe.

Macdonell, Arthur Anthony 1897. Vedic Mythology. Grundriss der Indo-Arischen Philologie und Altertumskunde, Band III. Strassburg: Verlag von Karl J. Trübner.

MacDowall, David W. 1975. The role of Mithra among the deities of the Kusana coinage. Hinnells, John R. (toim). Mithraic studies. Proceedings of the First International Congress of Mithraic Studies. Volume I. Manchester: Manchester University Press, lk 142-150.

MacDowall, David W. 1978. Mithra's Planetary Setting in the Coinage of the Great Kushans. Études Mithraiques. Acta Iranica 17, lk 305-316.

Mackenzie, Donald A. 1994. Myths \& Legends of India. London: Merchant Book Company Limited.

Marek, Christian 2010. Geschichte Kleinasiens in der Antike. München: Beck.

Mayerhofer, Manfred 1978. Die bisher vorgeschlagenen Etymologien und die ältesten Bezeugungen des Mithra-Namens. Études Mithraiques. Acta Iranica 17, lk 317-325.

Meillet, Paul Jules Antoine 1907. Le dieu Indo-Iranien Mitra. Journal Asiatique 10, lk 143-159.

Merkelbach, Reinhold 1994. Mithras. Ein persisch-römischer Mysterienkult 2. Auflage Weinheim: Beltz Athenäum.

Nyberg, Henrik Samuel 1966. Die Religionen des Alten Iran. Osnabrück: Otto Zeller.

Puhvel, Jaan 1978. Mithra as an Indo-European Divinity. Études Mithraiques. Acta Iranica 17 , lk 335-355.

Puhvel, Jaan 1981. Mithra as an Indo-European Divinity. Analecta Indoeuropaea. Delectus Operum Minorum Plerumque Anglice Aliquando Francogallice. Editorum Annos 1952-1977 Complectens. Innsbrucker Beiträge zur Sprachwissenschaft, Band XXXV. Innsbruck, lk 322-330.

Puhvel, Jaan 1997. Võrdlev mütoloogia. Eesti mõttelugu 12. Tartu: Ilmamaa.

Raditsa, Leo 1983. Iranians in Asia Minor. Yarshater, Ehsan (toim). The Cambridge History of Iran. Vol. 3 (1). The Seleucid, Parthian and Sasanian Periods. Cambridge: Cambridge University Press, lk 100-114.

Sagar, Krishna Chandra 2016. Kušaanide kultuuriline panus. Tlk Jaan Lahe. Akadeemia 9/10, lk 1644-1683; lk 1841-1853. 
Mitra kuju Indias ja Mithra kuju Iraani usundites - uurimus võrdlevast mütoloogiast

Schlerath, Berhard 1986. Mithra. Colpe, Carsten (toim). Wörterbuch der Mythologie 4. Götter und Mythen der kaukasischen und iranischen Völker. Stuttgart: Klett-Cotta, lk 393-398.

Schmeja, Hans 1975. Iranisches und Griechisches in den Mithrasmysterien. Innsbrucker Beiträge zur Sprachwissenschaft. Vorträge 13. Innsbruck: H. Kowatsch.

Schmidt, Hans-Peter 1978. Indo-Iranian Mitra Studies: The State of the Central Problem. Études Mithraiques. Acta Iranica 17, lk 345-394.

Schmidt, Hans-Peter. Mitra in old Indian and Mithra in old Iranian. Encyclopaedia Iranica (http://www.iranicaonline.org/articles/mithra-i - 10. november 2016).

Schwertheim, Elmar 2005. Kleinasien in der Antike. Von den Hethithern bis Konstantin München: Beck.

Shaked, Shaul 1980. Mihr the judge. Jerusalem Studies in Arabic and Islam 2, lk 1-32.

Sims-Williams, Nicholas 2012. Bactrian Historical Inscriptions of the Kushan period. The Silk Road 10, 76-80 (http://www.silkroadfoundation.org/newsletter/vol10/ SilkRoad_10_2012_simswilliams.pdf - 10. november 2016).

Soudavar, Abolala 2003. The Aura of Kings. Costa Mesa (California): Mazda.

Stausberg, Michael 2002. Die Religion Zarathustras: Geschichte, Gegenwart, Rituale. Bd. 1 Stuttgart: Kohlhammer.

Stausberg, Michael 2011. Zarathustra und seine Religion. München: Beck.

Stausberg, Michael \& Sohrab-Dinshaw Vevaina, Yuhan \& Tessmann, Anna (toim) 2015. The Wiley Blackwell Companion to Zoroastrianism. Wiley Online Library. Wiley Blackwell.

Sundermann, Werner. Bahman Yašt. Encyclopaedia Iranica (http://www.iranicaonline. org/articles/bahman-yast-middle-persian-apocalyptical-text - 10. november 2016).

Zaehner, Robert Charles 1961. The Dawn and Twilight of Zoroastrianism. Cambridge: Cambridge University Press.

Zeimal, E. V. 1983. The political history of Transoxiana. Yarshater, Ehsan (toim). The Cambridge History of Iran. Vol. 3 (1). The Seleucid, Parthian and Sasanian Periods. Cambridge: Cambridge University Press, lk 232-262.

Thieme, Paul 1957. Mitra and Aryaman. New Haven, CT: Yale University Press.

Thieme, Paul 1960. The "Aryan" gods of the Mitanni treaties. Journal of American Oriental Society 80, lk 301-317 (doi: 10.2307/595878).

Thieme, Paul 1975. The concept of Mitra in Aryan belief. Hinnells, John R. (toim). Mithraic Studies. Proceedings of the First International Congress of Mithraic Studies. Volume I. Manchester: Manchester University Press, Rowman and Littlefield, lk 21-33.

Thieme, Paul 2015. Mithra Avestas. Tlk Jaan Lahe. Akadeemia 11, lk 1998-2009.

Udam, Haljand 2001. Iraani kirjandus. Udam, Haljand. Orienditeekond. Eesti mõttelugu 37. Tartu: Ilmamaa, lk 66-84.

Vermaseren, Maarten J. 1963. Mithras, the Secret God. London: Barnes \& Noble. 
Vermaseren, Maarten J. 1965. Mithras. Geschichte eines Kultes. Stuttgart: W. Kohlhammer.

Wagner, Jörg 2012. Die Könige von Kommagene und ihr Herrscherkult. Wagner, Jörg (toim). Gottkönige am Eufrat. Neue Ausgrabungen und Forschungen in Kommagene. Darmstad \& Mainz: Philipp von Zabern, lk 43-60.

Widengren, Geo 1965. Die Religionen Irans. Die Religionen der Menschheit 14. Stuttgart: Kohlhammer.

Wikander, Stig 1938. Der arische Männerbund. Lund: Hakan Ohlsson.

Yarshater, Ehsan 1983. Iranian common beliefs and world-view. Yarshater, Ehsan (toim). The Cambridge History of Iran. Vol. 3 (1). The Seleucid, Parthian and Sasanian Periods. Cambridge: Cambridge University Press, lk 343-358.

\title{
Summary
}

\section{Mitra in India and Mithra in Iranian religions: A study on comparative mythology}

\author{
Jaan Lahe, Martti Kalda
}

Keywords: Avesta, India, Iran, Mithra, Mitra, mythology, Sanskrit, Vedic literature

This article is a systematic approach to the character of deity, who bears the name Mitra in India, but in Iran is called Mithra (later Mihr). The study aims to give answers to three questions: 1) What are the similarities between the Indian Mitra and the Iranian Mithra, if we leave aside the name of the deity? 2) What are the differences between these two deities? 3) What are the changes that the depiction of Mitra/Mithra has gone through in Indian and Iranian mythologies? To answer these questions, the article first gives an overview of Mitra in India, then of Mithra in Iran, and finally compares the two.

Both approaches start with a comprehensive overview of sources. In India the main source for the study of Mitra is Vedic literature (ca 1500/1200-600/500 BC), namely the Rigveda, Atharvaveda, Yajurveda, and Śatapatha Brāhmana. These sources are consistent, describing Mitra as a deity connected with the Sun, the incarnation of divine order, harmony, and friendship among mankind. Some light is thrown also on Mitra in post-Vedic literature, mainly in epic literature (ca 300/200 BC-200/300 AD).

In Iran, the sources are even more varied. They start with Iranian scripture Avesta (ca 1000-300 BC) and epigraphic sources from Achaemenian dynasty (6th-4th century $\mathrm{BC}$ ), and continue with written sources from Greek and Roman writers (6th century $\mathrm{BC}$ to 3rd century $\mathrm{AD}$ ), epigraphic material, and data from coins from Kushan (1st -3rd centuries $\mathrm{AD}$ ) and Sassanid periods (3rd-7th centuries $\mathrm{AD}$ ), not to forget Pahlavi writings from medieval Persia (7th-10th centuries AD). According to the sources, Iranian Mithra is a divine warrior, ruler of the worlds, judge of the dead, and protector against demons. He is still connected with the Sun, and helps the mankind, but more aggressively than Indian Mitra, who has ceded all his warlike attributes to his dual companion Varuna.

The article concludes that the cult of Mithra that was so influential in the Mediterranean region has probably borrowed more from Iran than India. 